\title{
A REVIEW OF THE CHALLENGES AND STRATEGIES OF DELIVERING SERVICES OF GENERAL INTEREST IN EUROPEAN RURAL AREAS
}

\author{
Nathalie Tent ${ }^{1}{ }^{(D)}$, Alexandru Brad ${ }^{2}(\mathbb{D})$, Juliane Klöden ${ }^{3}$, Alistair Adam Hernández ${ }^{4}{ }^{(D)}$, Jörn Bannert ${ }^{5}{ }^{(D)}$, \\ Alice Gebauer ${ }^{5}$ \\ ${ }^{1}$ Carl von Ossietzky University of Oldenburg \\ Ammerländer Heerstraße 114-118, 26129 Oldenburg: Germany \\ nathalie.tent@uni-oldenburg.de \\ ${ }^{2}$ Johann Heinrich von Thünen Institute, Federal Research Institute for Rural Areas, Forestry and Fisheries \\ Bundesallee 50, 38116 Braunschweig: Germany \\ alexandru.brad@thuenen.de \\ ${ }^{3}$ TU Dresden, Chair of Land Management \\ Helmholtzstraße 10, 01062 Dresden: Germany \\ juliane.kloeden@tu-dresden.de \\ ${ }^{4}$ Academy for Territorial Development in the Leibniz Association \\ Vahrenwalder Straße 247, 30179 Hannover: Germany \\ adam@arl-net.de \\ ${ }^{5}$ Leibniz University Hannover, Geodetic Institute \\ Nienburger Straße 1, 30167 Hannover: Germany \\ bannert@gih.uni-hannover.de•gebauer@gih.uni-hannover.de
}

\begin{abstract}
In many of Europe's rural regions, sociodemographic changes, the transformation of the labour market, and the advent of digitalisation pose significant challenges in safeguarding services of general interest (SGI). This paper draws on a broad literature review to identify the key challenges and potential adaptation strategies in three SGIs in four European countries. Our analysis explores potentials for redesigning the accessibility of these SGIs, restructuring their human and physical assets, and improving the coordination of their delivery. We argue that in the context of a fading welfare state, there is scope for improving the local coordination of state, private, and civil society actors in delivering SGIs in rural areas.
\end{abstract}

Keywords: firefighters, medical care, post-school education, rural areas, services of general interest, sociodemographic changes.

\section{Introduction}

Many rural areas in Europe have been struggling to maintain their services of general interest - SGIs (Fassmann, Rauhut, da Costa \& Humer, 2015; Rauhut \& Komornicki, 2015; ARL, 2016). Indeed, in the light of the challenges posed by shrinking populations, ageing, and uncertain economic futures, the redesign of SGIs requires adaptation strategies which draw on innovative thinking and practical experimentation (Syssner, 2020; Chartier et al., 2021). 
Curiously enough, recent policy shifts have been effective in shaping workable networks of SGIs in urban areas. Nonetheless, the market-based model they follow tends to reach its limits when confronted with the basic characteristics of rural territories. Amongst these, greater distances, lower populations, and consequently lower numbers of users negatively impact the financial viability of SGIs (OECD, 2010). To complicate matters further, these characteristics are also the prime culprits which aggravate the deficiencies in SGI provision (Hahne, 2009; Nadler, 2017).

For the second half of the past century, welfare states have typically directly addressed these externalities. Yet over the past decades, neoliberal and market-based policy arguments have pushed for a withdrawal of the state in all areas of the public sector. As a consequence, multiple non-state actors have entered the SGI arena as potential providers. In these constellations, the role of state organisations has been gradually shifting from one of an active provider to that of a bureaucrat which acts more as an invigilator. In the current setup, private and not-for-profit SGI providers must balance between financial thriftiness and fulfilling state-sanctioned standards, all while being part of a competitive landscape with other providers.

The state of affairs which the afore-described process aims for is by no means a consistent occurrence across Europe. In fact, shifts in SGI provision have multiple facets in different countries, with outcomes shaped by traditional arrangements within the SGIs themselves, specific forms of national government, situated political outcomes, and regional socio-economic particularities. To reflect this variegated landscape, our aim in this paper is to provide a comparative analysis which probes into different SGIs in multiple European countries. We ask the following research question: which challenges impact the provision of SGIs, and which solutions to these challenges contribute towards securing the provision of SGIs in Europe's rural areas?

To answer this question, we follow a research design which compares three SGIs in four European countries. Our selection of SGIs seeks to provide concrete examples which are illustrative of demographic changes in rural areas. We hence focus on medical and nursing care (as an area in which the balance between climbing demand and workforce shortages is increasingly difficult to negotiate), fire and rescue services (where the reliance on volunteers can no longer be taken for granted), and post-school education (where its typical concentration in urban centres has traditionally acted as a barrier for rural development) (Martin \& Demyen, 2019; NMIS, 2019; Kulicke, 2021). The countries we have selected (Austria, Germany, Scotland, Sweden) offer a varied palette of rural areas, ranging from sprawling suburbia to remote, sparsely populated territories.

We begin our paper by exploring the notion of SGI itself and reviewing the main factors which shape SGI provision in rural Europe. We then move on to outline the methodology that underpins our analysis. After this, we briefly describe the national contexts in which we conduct our analysis. This is followed by two sections which describe the challenges and new strategies of securing SGIs in rural areas. We finalise the paper by drawing a number of conclusions and advancing suggestions for further research on the topic.

\section{Understanding SGIs and their particularities in rural Europe}

In this section we aim to briefly describe the core term we employ in this paper, namely SGI. We first engage with its normative dimensions and ambiguities. We follow this with a discussion on the key trends which shape SGIs in Europe's rural areas. 


\section{What are SGIs?}

The normative term of SGI gained traction during debates on liberalisation within the European Union (EU) Single Market and on promoting territorial and social cohesion across the Union. A widely quoted definition depicts SGIs as 'services that public authorities of the Member States classify as being of general interest and, therefore, subject to specific public service obligations' (EC, 2011).

This definition is purposefully ambiguous as it is broad. For one, the responsibility for establishing the scope of SGIs as well as the details of the general interest they ought to serve lies with the Member States. EU institutions lack competences on the matter beyond safeguarding the competition and state aid legislation, and pleading for a cohesive development of the European territory.

A second issue stemming from this definition concerns the lack of clarity over the economic or non-economic nature of these services, and hence the jurisdiction of the EU's competition rules upon them (Bauby, 2011). While the above-quoted document differentiates between Services of General Economic Interest (SGEI) and Social Services of General Interest (SSGI), these two subcategories cover both economic and non-economic services. In practice, however, pinning down the economic nature of a service has proven to be a difficult undertaking which hinges on politically contested fundamental interpretations of the role of the public and private sectors (Bjørnsen, Foss \& Johansen, 2015).

A third difficulty that relates to the above is the lack of clear provisions concerning the type of actors which ought to deliver SGIs. Such actors may be public, private, civic, or hybrid. Critical voices have highlighted the uprise of a consumerist approach towards delivering SGIs, as market principles have reconfigured 'the once dominant forms of relationship between states and their citizens' (Clarke, 2007). The proliferation of market governance also stands to permeate SGIs which have traditionally relied on civic engagement - e.g., the volunteer firefighters (Dombrowsky, 2008). In addition to this, the relationship between actors involved in providing SGIs is increasingly complex, and, in some cases, fuzzy to the lay person or the end beneficiary of the service. This ambiguity is fuelled by the broadness of term 'services' itself, which might include 'products, activities, facilities, utilities, arrangements, institutions, organisations, industries, etc' (Bjørnsen et al., 2015).

A fourth challenge in defining SGIs relates to the thorny process of pinning down 'public service obligations'. As this notion is too complex to be useful for scientific inquiries, Bjørnsen et al. (2015, p. 62) suggest a pragmatic analytical take which brings forth the 'rights of citizens and enterprises to expect certain actions by public authorities and service providers to ensure their access to a specific level of selected services'. This approach points towards embracing systemic traditions, many of which have been, up to recent, shaped by a strong state presence. Adding to this, Humer, Rauhut and Fassmann (2015) argue that territorial factors (e.g., population density, geographical features) also shape the provision of SGIs, especially insofar as accessibility and viability is concerned. Beyond this, SGI provision is also subject to temporal aspects. Shifts in societal values and economic conditions, together with institutional and technological innovations, all place SGIs in an inextricable dynamism. These changes might influence operating standards, quality or cost, but might also render entrenched provision models obsolete (Humer et al., 2015).

All in all, current conceptual understandings of SGIs (be them of a policy or academic nature) lean towards highlighting the salience of contextual factors which shape their design and patterns of use. To us, this signals that a grounded, comparative research approach can yield relevant theoretical insights into the challenges of, and new approaches towards securing the provision of SGIs. 


\section{Shifts in the design and provision of SGls in rural areas}

Traditionally, both the demand and the supply of SGIs in rural areas have been lesser than in urban agglomerations (Rauhut, Smith, Humer, Ludlow \& Borges, 2013). In the light of demographic and economic change, European integration, increased population mobility, and technological advances, the adaptation of SGI provision in rural Europe has picked up in speed and intensity. This process has resulted in quality improvements and closures alike. Undoubtedly, there are multiple intricate factors and external conditions which have shaped the evolution of SGIs. While our aim is not to conduct a comprehensive review of these process and conditions, three salient aspects come forth as relevant for grasping the state of SGIs in rural Europe

A first aspect relates to the undoing of the welfare state through the uprise of neoliberal and network governance thought. In Europe, ever since its consolidation during the 1960s, the ideal of the welfare state has been steadily eroded in response to cyclical economic shocks and uprise of the globalised economy. The demise of Keynesian economics in the early 1980s, the signing of the Maastricht Treaty in 1992, and the uprise of the growth-driven competitiveness discourse in the EU's regional development policies at the turn of the millennium were key turning points which have weakened the idea of state-provided public goods. Most recently, the post-2009 crisis policy of financial austerity has led to cuts in SSGIs, a reduction in health spending, further steps towards liberalising the labour market (e.g., by enabling more flexibility, less protection, and lower labour costs), and a reduction in public investments (Stetter, 2018).

The transformation of the welfare state is strongly intertwined with the rise of new public management and market governance principles - the second key aspect we consider to be relevant. Put briefly, these ideals promote principles of efficiency, performance, and financial diligence and transparency in public administration. Consequently, the public service provider role was put up for competition between public agencies, firms, and not-for-profit bodies (Dunleavy \& Hood, 1994). In spite of these shifts, critical voices argue that the marketisation of SGIs is rather an ideal than an empirical reality. An issue considered to be particularly problematic is that neoliberal reforms have favoured the fragmentation of SGI provision (amongst other functions fulfilled by the state) by establishing (complex) networks of service delivery rather than the pure markets and hierarchies that have been advocated for.

It is worth pointing out that the policy instruments which sustained these shifts in SGI provision did not specifically target rural areas. In fact, most strategic shifts were sectoral in nature, with negative externalities expanding into depriving urban and peripheralizing rural areas alike (FischerTahir \& Naumann, 2013). However - and this is the third aspect we hold as relevant - rural development itself also underwent a paradigmatic shift from neoclassical location theories towards a place-based endogenous and neo-endogenous approach (Cejudo \& Navarro, 2020). In concrete terms, this meant that state-driven equalisation and structural adjustment programmes gradually shifted towards commodifying local assets and stimulating community involvement, albeit in a framework established by the state (OECD, 2016; Gkartzios \& Lowe, 2019). As such, centrallysteered interventions have been gradually replaced by small, predominantly local-bottom-up generated projects (Atterton \& Skerratt, 2017).

In rural areas where economic growth could no longer be sustained, the withdrawal of the state has led to a decline in the availability (e.g., as facilities became unviable or the personnel lacked) and the accessibility (e.g., through service concentration) of SGIs. Nonetheless, the ideal of maintaining a territorially balanced supply of SGls tends to occupy a prominent position in the political discourse. The Territorial Agenda 2030, for instance, holds improvements in the accessibility, proximity, affordability, and quality of SGIs as essential prerequisites for securing life 
quality and business development prospects in rural areas. Contrasting these two observations, we can sense a certain duality between policy action and political thought. We view this to be emblematic of a key conundrum in current strategic policy choices concerning the role of SGI provision in rural development: on the one hand adapting and (re-)sizing SGIs to the needs of a local community (in accordance to a minimum standard) vs. proactively stabilising and investing in SGls on the other hand, with the aim of promoting local development and prevent further population loss (ARL, 2016).

Taken together, the three afore-mentioned aspects depict a mix of developments which have shaped current arrangements in SGI provision. Contemporary challenges in maintaining SGIs in rural areas are experienced differently, with outlooks varying in accordance to regional socioeconomic conditions and the provisions which govern each SGI in part.

\section{Methodology}

The methodological design of this paper seeks to enable an exploratory cross-country comparison of the challenges and new strategies of delivering SGIs in rural Europe. The research rests on the comparison of three SGIs - medical and nursing care, fire and rescue services, and post-school education - in four European countries - Germany, Austria, Scotland, and Sweden (Fig. 1).

The rationale for selecting these SGIs is anchored in two key principles. First, the selection was restricted to SSGIs with the purpose of focusing the analysis on the effects of services which address the fundamental risks and vulnerabilities of life (according to EC, 2011). Secondly, the focus was set on SSGIs with contrasting governance structures rather than on multiple branches of a particular SSGI. The created the premises for exploring the effects of demographic change on their delivery, the adaptions to these challenges, and the contributions made by the SSGIs towards local development in general.

As previously argued, the fuzzy nature of SGI is not well suited for delineating concrete services. This issue was overcome in this research by grounding the selection in Germany's federal policy landscape - a setting in which the authors are institutionally anchored. The 'Programme of Action for the Regional Provision of Public Services' (in German: Aktionsprogramm regionale Daseinsvorsorge - ArD, 2011-2015) offered a good starting point, as an instrument for financing innovations in public services within rural areas. The programme's conception emphasised the three selected SSGIs as highly relevant for rural development (BMVBS, 2012). Moreover, the programme's final report has selected the three SSGIs for showcasing the best practices that have been implemented through the programme (BMVI, 2016).

Concomitantly, beyond the concrete actions pursued through targeted policy instruments, the prominence of the afore-mentioned SSGIs in the federal policy discourse was also considered. The 2017 Federal Spatial Planning Report has argued that, amongst other SGEls, the three selected SSGIs exert a significant influence upon local and regional living standards. The report also highlights that the quality and accessibility of these SSGIs have been impacted by demographic change, albeit to different extents (BBSR, 2017, p. 63-64). The three SSGIs are also prominently featured in the 2020 Federal Government Report on the Development of Rural Areas, where they are described to be particularly prone to shrinkage and centralisation (BMEL, 2020a, p. 34). Moreover, Germany's Federal High-Tech Strategy (BMBF, 2018) features health and nursing care, and continuing education as key action fields, highlighting the challenges associated with maintaining these services in structurally weak rural areas. 
The review of the German context has led to the working hypothesis that other European countries with considerably vaster rural areas than Germany have been more successful in futureproofing SGIs in these spaces. The selection of other European countries which could act as a basis for comparison followed two key principles. First, the selection targeted countries with population densities which are significantly lower than Germany's, following the logic that the need for adapting SGls in these areas is more salient. A second goal was to select contrasting state models. Although widely critiqued as an analytical concept, Esping-Andersen's (1998) categorisation of welfare states served as a key descriptive tool for differentiating national traditions of organising SGIs.

The country selection was also guided by the transnational comparative reports which have accompanied the German ArD programme (BMVBS, 2013; BMVI, 2015). The process was finalised with the help of personal contacts in the frame of the $\operatorname{InDaLE}^{1}$ project, in which this research is conducted.

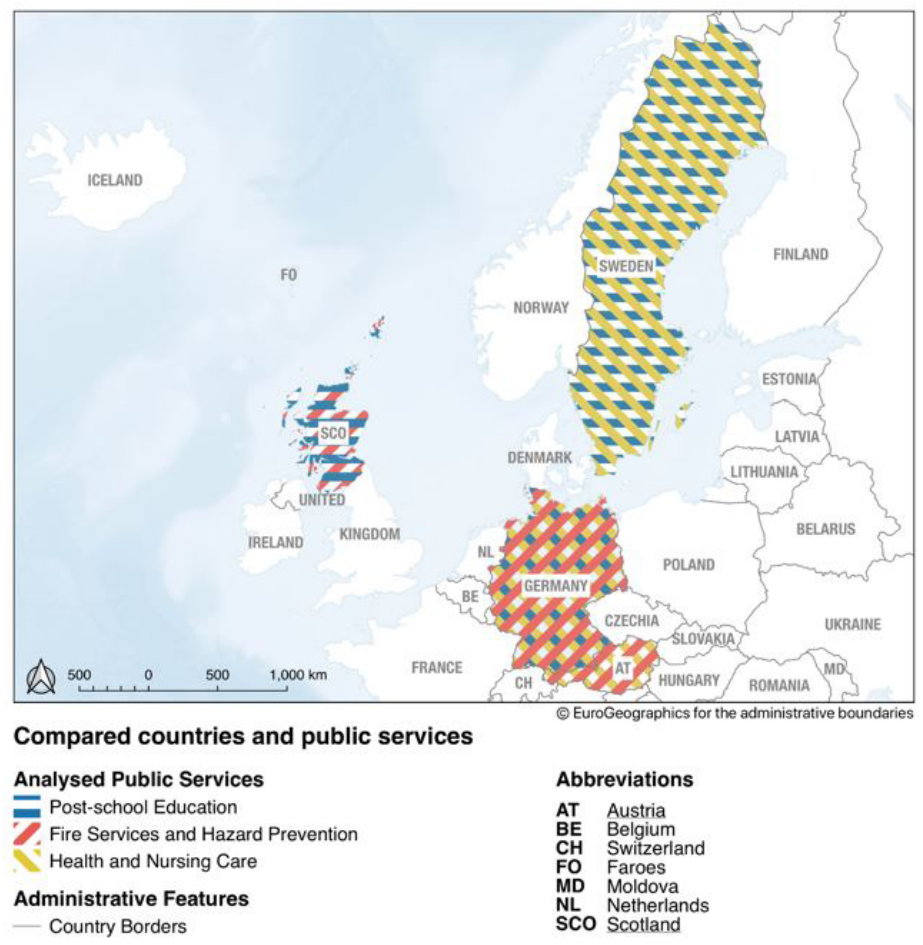

Figure 1. Selected countries and the allocation of the analysed SGIs

The selected study countries offer exemplary solutions to challenges in the selected SSGIs. In Austria, mobile health services cover the nation's territory in its entirety (Favry \& Hiess, 2008). The country also features a similar firefighting system to Germany. Sweden is considered to be a pioneer in the use of digital solutions both in education and in medical care (Rennie, Greller \& MacKay, 2002). Finally, Scotland's firefighting system starkly differs the German and Austrian one, hence offering a contrasting example. The country has also implemented models of post-school education which combine decentralised structures with e-learning (Mose \& Jacuniak-Suda, 2016).

The data used in this paper stems from secondary and tertiary sources. We started our inquiry through an in-depth literature review of the SGIs in the respective studied countries and in Europe in general. The review focused on organisational aspects, the governance of the respective SGI, the

\footnotetext{
1 The InDaLE project (2020-2022) looks to understand the factors which favour the long-term establishment of innovative projects that target SGIs in rural areas. More details available at www.indale.org/en.
} 
particularities of service delivery in rural areas (including key challenges and recent developments), and new potential strategic directions in their delivery. This review was complemented by a significant body of grey literature which encompassed governmental strategies, position papers, expert group reports and statistics for the studied SGIs. In addition to this, we analysed reports on implemented projects, from where we have derived key strategic approaches for maintaining SGIs. These were classified in the current scientific debate of the respective SGI area through a literature search.

One key limitation in our approach is that due to our lack of knowledge of the Swedish language, we limited our literature review to German and English sources. Swedish project reports could only be considered to a limited extent.

\section{National contexts}

In many German rural regions, maintaining a fair access to SGIs has become a challenge in itself. The political goal of striving for similar living standards across the country has become increasingly difficult to fulfil, as the population of many rural areas has been shrinking and ageing (see Table 1). Statistical projections foresee that peripheral rural regions will likely be significantly impacted by these demographic changes, as migration towards these areas is relatively weak, birth rates are low, and many young people choose to leave for metropolitan regions (Maretzke, Hoymann, Schlömer \& Stelzer, 2021). As such, the gap between Germany's core metropolitan areas and structurally weak rural regions is expected to widen in the near future. These trends pose fundamental challenges in securing a minimum offer of public services in rural regions (ARL, 2016).

Demographic change is not an issue confined to Germany. Indeed, many regions in Europe have had to grapple with declining trends (see for instance Lang \& Haunstein, 2017). In Austria, Scotland, and Sweden the population's growth rate tends to be lower in the countries' rural areas. A contributing factor to the territorial imbalances is the skewed geographical distribution of the population. In Austria, mountainous terrain makes up $70 \%$ of the country's territory. Specific to these alpine regions are settlement structures lined up along valleys, a low population density, and a partially hampered connectivity due to the rugged terrain. On the other hand, both Scotland and Sweden feature pronounced north-south gradients of urbanisation, with relatively dense urban structures in the south, and sparsely populated regions towards the north - regions that are typically labelled as Europe's classic geographical peripheries. As such, only 15\% of the population lives in Scotland's rural areas, while in Sweden this number reaches 20\%. Ageing also tends to be more pronounced in the rural areas of Scotland and Sweden, with higher and more intensifying old-age dependency rates. In contrast to this, Austria's spatial demographic trends are more balanced across urban, rural, and intermediate regions, with roughly a third of the population living in each type of space. Moreover, out of the analysed countries, the ageing coefficient is at its lowest in Austria.

In spite of these demographic shifts, the economic landscape of the rural areas in the analysed countries is relatively solid. We cannot deny that in spite of relative differences within the countries themselves, Austria, Germany, Scotland and Sweden feature some of Europe's most developed rural areas (Lang \& Haunstein, 2017). As such, in spite of a low contribution to Scotland's GDP (Table 1), the country's most rural and peripheral area - the Highlands and Islands - has a dynamic economic base with low unemployment and a high number of self-employed entrepreneurs (HIE, 2019). In a similar fashion, Austria's rural areas achieve very high GDP values (EC, 2017). Their economic circumstances are mainly shaped by the innovative economic activities which are settled there, by their favourable location at traffic crossroads, and by their success as tourist areas. Sweden's northern peripheral regions also score well in the EU's regional innovation scoreboard 
where merging innovative sectors such as bio-based industries (e.g., textiles, nature-based tourism and bioenergy) have experienced a rise in employment (NCM, 2020).

Table 1. Overview of a key set of socio-economic indicators in the analysed countries

\begin{tabular}{|c|c|c|c|c|c|c|c|c|c|c|c|c|}
\hline Analysed countries & \multicolumn{3}{|c|}{ Germany } & \multicolumn{3}{|c|}{ Austria } & \multicolumn{3}{|c|}{ Scotland } & \multicolumn{3}{|c|}{ Sweden } \\
\hline Key indicators (2009-2019) & \begin{tabular}{l}
\multicolumn{1}{c}{} \\
芳 \\
D
\end{tabular} & 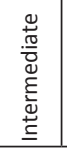 & 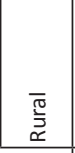 & 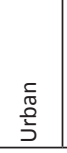 & 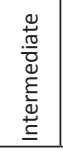 & 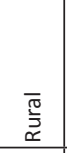 & 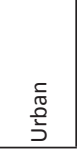 & 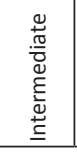 & 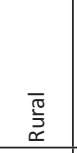 & 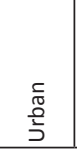 & 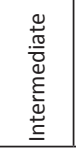 & 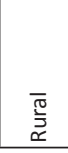 \\
\hline Population density ${ }^{\text {a) i) }}$ & \multicolumn{3}{|c|}{235} & \multicolumn{3}{|c|}{108} & \multicolumn{3}{|c|}{70} & \multicolumn{3}{|c|}{25} \\
\hline Share of national population ${ }^{\text {b)c c) d) e) }}$ & $35 \%$ & $42 \%$ & $23 \%$ & $31 \%$ & $31 \%$ & $39 \%$ & $41 \%$ & $42 \%$ & $15 \%$ & $39 \%$ & $41 \%$ & $20 \%$ \\
\hline Population change ${ }^{\text {b)c d) e) }}$ & $0.9 \%$ & $0.8 \%$ & $-0.8 \%$ & $5.6 \%$ & $3.6 \%$ & $0.5 \%$ & $5 \%$ & $2.9 \%$ & $1.8 \%$ & $8.3 \%$ & $3.9 \%$ & $0.1 \%$ \\
\hline 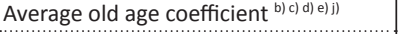 & 34 & 37 & 35 & 25 & 26 & 26 & 27 & 34 & 38 & 28 & 39 & 46 \\
\hline Old age coefficient change ${ }^{\text {b)c c) d) e) }}$ & $0.1 \%$ & $4.8 \%$ & $3.9 \%$ & $1.5 \%$ & $7.9 \%$ & $5.3 \%$ & $10.6 \%$ & $21.3 \%$ & $21.1 \%$ & $6.7 \%$ & $12.9 \%$ & $13.9 \%$ \\
\hline Average share of national GDP f) k) & $51 \%$ & $36 \%$ & $13 \%$ & $36 \%$ & $31 \%$ & $33 \%$ & $65 \%$ & $27 \%$ & $8 \%$ & $57 \%$ & $35 \%$ & $8 \%$ \\
\hline GDP change f) k) & $2.2 \%$ & $5.8 \%$ & $7.2 \%$ & $3.3 \%$ & $1.1 \%$ & $4.6 \%$ & $2.3 \%$ & $3.2 \%$ & $1.4 \%$ & $10.3 \%$ & $3.4 \%$ & $2.9 \%$ \\
\hline Internet download speed (Mbps) glII & 97 & 79 & 50 & 72 & 53 & 36 & 86 & 65 & 32 & 137 & 116 & 95 \\
\hline
\end{tabular}

Source: authors' calculation based on:

a) OECD.Stat, Table Regional Demography: Population density and area, large TL2 and small TL3 regions.

b) Statistische Ämter des Bundes und der Länder, Table 12411-02-03-4: Bevölkerung nach Geschlecht und Altersgruppen (17) - Stichtag 31.12. - regionale Tiefe: Gemeinden).

c) Statistik Austria, Table debevstandjbab2002: Population at the beginning of the year since 2002 (regional status of 2020).

d) statistics.gov.scot, Table Population Estimates Summary (Current Geographic Boundaries).

e) Statistics Sweden, Table BE0101N1 Population by Region, marital status, age and sex. Year 1968-2020.

f) OECD.Stat, Table Gross Domestic Product, Small regions, TL3.

g) European Data Journalism Network, Average internet speed across Europe.

Observations:

h) Following the OECD urban/rural typology.

i) Population per km2. Data only available for 2020.

j) Calculated as the ratio between the old inactive population (65 years and older) and the working population (20-64 years old).

k) Data only available for 2008-2018 at NUTS-3 level.

I) Data only available for 2020 .

All analysed countries face challenges in upholding SGIs in their rural areas. In Austria, there is an ongoing struggle in maintaining infrastructures, especially in shrinking and structurally weak rural areas. Indeed, the variety and quality of public services have been gradually reduced in many places. This is especially true for social and health facilities (Machold \& Tamme, 2009; ÖROK, 2020). Analogous to this, Sweden faces growing challenges in ensuring SGIs in its shrinking rural areas, not least because about $70 \%$ of municipal expenditures are financed by a direct municipal income tax (Wollmann, 2008). Last, local communities in northern Scotland have had to deal with special challenges for decades. Unplanned settlements in the countryside, the spatial structure of the islands and demographic change meant that new solutions had to be found early on to preserve rural public services (Mose \& Jacuniak-Suda, 2016).

\section{The challenges of delivering SGIs in rural Europe}

In this section, we detail the key challenges which impact the provision of the three selected SGIs in rural Europe (Table 2). 
Table 2. Overview of the key challenges in the studied SGIs*

\begin{tabular}{|c|c|c|c|c|}
\hline & Demographic change & Geographic conditions & Societal challenges & SGI-specific \\
\hline \multirow{2}{*}{ 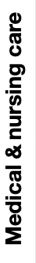 } & $\begin{array}{l}\text { An increase of elderly population results in } \\
\text { an increase in the demand of medical and } \\
\text { nursing care. }\end{array}$ & $\begin{array}{l}\text { Allocation problems due to settlement of } \\
\text { new physicians. }\end{array}$ & $\begin{array}{l}\text { Integration of skilled foreign workers to } \\
\text { meed labour demands. }\end{array}$ & $\begin{array}{l}\text { The current expansion of educational offers } \\
\text { is yet to meet the demand for young } \\
\text { professionals. }\end{array}$ \\
\hline & $\begin{array}{l}\text { Ageing workforce, insufficient young } \\
\text { recruits. }\end{array}$ & $\begin{array}{l}\text { Difficult accessibility due to long distances } \\
\text { leads to longer waiting times. }\end{array}$ & $\begin{array}{l}\text { Increase in formal care as informal care } \\
\text { from relatives decreases. }\end{array}$ & \\
\hline \multirow{3}{*}{ 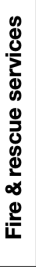 } & $\begin{array}{l}\text { Decrease in the number of volunteer } \\
\text { firefighters. }\end{array}$ & $\begin{array}{l}\text { Longer commutes result in low daytime } \\
\text { availability. }\end{array}$ & Difficulty in recruiting new volunteers. & $\begin{array}{l}\text { More interventions caused by natural } \\
\text { disasters. }\end{array}$ \\
\hline & $\begin{array}{l}\text { Ageing populations require more } \\
\text { assistance. }\end{array}$ & & $\begin{array}{l}\text { Changed societal perceptions on } \\
\text { volunteering. }\end{array}$ & $\begin{array}{l}\text { Increasing costs and complexity of } \\
\text { operation and interventions. }\end{array}$ \\
\hline & & & & $\begin{array}{l}\text { Training demands are high and time } \\
\text { consuming }\end{array}$ \\
\hline \multirow{2}{*}{ 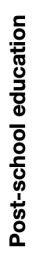 } & $\begin{array}{l}\text { Declining number of young people leads to } \\
\text { closures of educational facilities. }\end{array}$ & $\begin{array}{l}\text { Educational institutions are overwhelmingly } \\
\text { centralised; young people need to leave } \\
\text { rural regions to attend higher education } \\
\text { courses. }\end{array}$ & $\begin{array}{l}\text { Rigid structures in the education } \\
\text { system results in lacking support for } \\
\text { individual educational pathways. }\end{array}$ & $\begin{array}{l}\text { Missmatch between educational offers and } \\
\text { skills demanded in the field of labour. }\end{array}$ \\
\hline & $\begin{array}{l}\text { Lack of skilled workers even in thriving } \\
\text { rural regions. }\end{array}$ & $\begin{array}{l}\text { Poor broadband and public transport } \\
\text { infrastructures worsen accessibility. }\end{array}$ & $\begin{array}{l}\text { The advent of digitalisation in the } \\
\text { workplace and changes in the structure of } \\
\text { the labour market require retraining } \\
\text { continuous training. }\end{array}$ & $\begin{array}{l}\text { Educational institutions lack the technical } \\
\text { equipment to provide learners the skills } \\
\text { needed in the modern economy. }\end{array}$ \\
\hline
\end{tabular}

* The extent to which the studied countries are affected by a particular challenge is reflected in the size of the flags. 


\section{Medical and nursing care}

Especially in peripheral rural areas, securing medical and nursing care is increasingly difficult. The long distances that must be travelled is a significant factor which limits the population's access to these services. Moreover, the low population density rises the cost, availability, and potentially also the quality of an SGI (Humer et al., 2015). Trends such as demographic change and urbanization further exacerbate problems in providing health and nursing care (Richter et al., 2019).

In essence, the pronounced ageing of the population in rural areas (see Table 1 ) is directly proportional to the demand on medical and nursing services. As this phenomenon is unlikely to reverse in the near future, the number of people suffering from complex, multiple, or age-related diseases will continue rise (CFS, 2013). In 2017, 28\% of those aged 65 or older in Sweden already suffered from multiple chronic diseases. In Austria, this proportion reached 32\%, in Germany $47 \%$ (OECD, 2020). This leads to a curious development, namely: while the sustainability of other SGIs is challenged by the decline of their demand groups, the capacity of medical and nursing care facilities risks being pushed to the limit, hence increasing the need to adapt by expanding (SchmitzVeltin, 2006). This challenge is furthered by societal changes occurring over the past decades. New family structures, a rise in the number of single households, and a decline in birth rates result in fewer informal care offers for the elderly being provided within the family and circle of nearby relatives. At the same time, people increasingly expect to live in their own homes for as long as possible. As a result, not only is the general demand for medical and nursing care increasing, but so are the demands on their quality and versatility (Gruber, Fassmann \& Humer, 2015).

In addition to challenges posed by demand, the supply of medical and nursing care is under increasing pressure. Particularly the declining number of youngsters in rural areas leads to a decline in the critical mass required for financing this SGI. This sets already strained public budgets under even more pressure. The spatially imbalanced population development trends therefore also drive spatial inequalities in the distribution of medical and nursing care (Gruber et al., 2015). This has direct implications on labour force availability for nursing care in rural areas (OECD, 2020). Service providers in rural areas in general, and the northern regions of Sweden in particular, face difficulties in recruiting physicians. In Sweden, this process is aggravated by the Free Choice Reform - a policy provision which promotes a free establishment right for health care providers and which has generally led to a concentration of physicians in urban areas (OECD, 2017b).

The allocation problem described above is also exacerbated by demographic change. In the wake of the upcoming wave of retirements, a further decline in the availability of medical staff is expected, while the urge to find successors in rural areas becomes ever more pressing (Girard, 2003). Moreover, an aging healthcare workforce creates additional challenges in delivering outpatient care (OECD, 2017b) - a problem which is particularly prevalent in Germany (Kreiser, 2014; BMEL, 2020b) and Austria (OECD, 2019).

In addition to the afore-described workforce problem, there is a general shortage of specialists in both medical and nursing care. For example, Sweden relies on foreign-trained physicians to meet the demand for trained medical personnel. Even though the capacity of medical faculties in Sweden is growing, it is still increasing at a slower rate than the demand for physicians (OECD, 2017b).

Similar staffing problems can be observed in nursing care. For example, in Austria, a high proportion of outpatient care is provided informally by relatives, who, in turn, also require increasingly more support. However, the availability of informal care is expected to decline in the coming years, leading to an increased demand for formal care - i.e., hospital care, long-term care, and care for the elderly (Fernsebner-Kokert, Osztovics \& Kovar, 2018). 
Taken together, the described challenges can lead to problems in the accessibility of medical and nursing care in rural areas. The long distances to the closest care facility and long waiting times for treatments are key issues to be overcome in securing the provision of this SGI (OECD, 2020).

\section{Fire and rescue services}

A wide range of actors are involved in delivering fire and rescue services-e.g., firefighters, paramedics, or specialised support services. Our focus in this paper is on volunteer firefighters as local first line responders to fires and emergencies. In Germany and Austria, rural firefighting is highly decentralised and is mainly delivered by volunteers, which constitute $95 \%$ and $99 \%$ of the national firefighting force respectively (ÖBFV, 2017; DFV, 2018). Moreover, the local fire service is also an integral part of the social fabric of many German and Austrian villages (DFV, 2020). In contrast to this, in the UK, a mix of full-time, part-time and volunteer firefighters provides this SGI, while firefighting is perceived as a state-delivered service in its own right (Halliday, Asthana, Hewson \& Gibson, 2013). Scotland's volunteer and part-time firefighters comprise $45 \%$ of the firefighting force (SFRS, 2018a), with the remainder $55 \%$ of the firefighters working as full-time employees.

In the analysed countries, shifts in the demographic structure and labour market inevitably impact the service's dependability, but also lead to changes in people's readiness to engage in delivering the service (SG, 2016; Geier, 2017; Clar, Löschner, Nordbeck, Fischer \& Thaler, 2021). One of the most palpable effects of demographic change is the steadily shrinking number of volunteer (and, in Scotland, retained) firefighters. This phenomenon is particularly prevalent in Germany and in Scotland, where the number of volunteer and retained firefighters has dropped by $3 \%$ and $7 \%$ respectively since 2011 (ÖBFV, 2017; DFV, 2018). In Austria, on the other hand, while the number of active firefighters has remained constant, little attention has been warranted to the long-term implications of demographic change in natural hazard risk planning. Particularly problematic is the rising share of the elderly in affected communities and the practical difficulties associated with their rescue (Clar et al., 2021). In fact, all three countries highlight the salience of adapting the emergency response system to natural disasters, pointing out at the increasing number of incidents caused by climate change - for instance, floods, severe storms, or forest/grassland fires (ÖBFV, 2015; AGBF Bund \& DFV, 2020; DStGB \& DFV, 2020; SFRS, 2020a).

A second broader societal process impacting volunteer firefighting organisations is the changing nature of civic engagement. The recruitment and retaining of motivated volunteer and parttime staff in these organisations are indispensable. Nonetheless, a number of aspects intrinsic to the job stand to overburden firefighters. First of all, the work itself is psychically and physically demanding when compared to other civic engagement areas (e.g., sport associations). A second aspect is the implicit requirement to commit to rigorous initial and ongoing training alongside a full-time job (Mitchell \& Henderson, 2018; Olk, 2018). A third factor is the rather atypical topdown, to a certain extent militarist organisational model employed in the firefighting services (Buchner, 2014), a model which is by-and-large at odds with the deliberative values underpinning contemporary liberal societies. Taken together, the afore-mentioned encumbering factors stand to erode firefighters' motivation to join or remain active in the service. Studies show that the effects of these processes are particularly discernible in Germany (BMI, 2010) and in Scotland (Maclean, 2002; Halliday et al., 2013).

The effects of the afore-mentioned broad societal processes bring about operational challenges for the fire services. A first challenge stems from the increased workforce mobility, with people living in the rural areas of Germany, Austria, and Scotland generally having longer commutes (Statistik Austria, 2015; NRS, 2016; BBSR, 2020). In some places, this trend has rendered 
firefighters' day-time availability as unattainable (see for instance BBSR, 2009; OÖL, 2012; Mitchell \& Henderson, 2018). This issue is ever more salient in places with relatively few employers (Meier \& Barth, 2007).

A second operational challenge relates to financial sustainability. Rising costs in the running and upgrading of the service, together with an increase in the number and the complexity of interventions bring about financial difficulties in safe-guarding a comprehensive physical presence of fire and rescue services (see for instance ÖBFV, 2019). With financial efficiency often enshrined as a central principle in running the service (e.g. SG, 2016), debates about downsizing and spatial concentration of facilities and functions have been ongoing in all three analysed countries.

\section{Post-school education}

In post-school education and training, demographic change has far-reaching consequences for the maintenance of vocational schools, colleges, and further education centres in rural regions (OECD, 2021). Young people are leaving rural regions in search of better education and training opportunities, thus furthering local demographic challenges (see Table 1). In the light of this, educational institutions in rural regions have the potential to become a decisive local development asset. Their benefits are threefold: they guarantee training and qualification, they are a cornerstone in economic development, and they can shape a region into a positive place of learning.

Lifelong learning is also seen as an indispensable factor by policy-makers, even though investments in human capital do not automatically attract businesses (Jonda, 2009). Universities are also considered to be a source of knowledge for innovations, as they absorb external knowledge and disseminate it across the region. Close cooperation between universities and companies is hence crucial for the successful implementation of new innovations (Peer \& Penker, 2016). However, in the light of demographic changes, it is essential that skills which are in local demand are trained on site (Jonda, 2009). Nonetheless, educational institutions cannot act as the sole drivers in stimulating regional recovery efforts. This process also requires additional infrastructure, investments, and the support of regional actors (Peer \& Penker, 2016; Pinheiro, Šima, Young \& Kohoutek, 2018).

A key issue however remains the high centrality of higher education institutions which renders them less accessible to those living in areas with lower population density (Humer et al., 2015). As people need to travel further to reach these services, access may, access may be hindered by a lack of adequate transport infrastructure and broadband services (Pavis, Platt \& Hubbard, 2000). Another challenge is posed by a change in paradigm, as skill-focused learning and the support of individual educational pathways is increasingly replacing rigid, degree-based education (Daheim, Wintermann, Glenn, Korn \& Schoon, 2019). Such opportunities are significantly more limited in rural areas in comparison to large cities.

In all studied countries, attracting skilled workers through place marketing strategies is a key approach in overcoming regional disparities. Nonetheless, even in rural areas with a strong economy (e.g., in Germany), companies face difficulties in recruiting adequately skilled workers. This is exacerbated by rapid technological change and shifts in the labour market, which reinforce the importance of training opportunities throughout a person's working life (Giacometti \& Cuadrado, 2020). Yet the intensifying pace of labour market transformations (e.g., through the digitalisation of the workplace, sector shifts) renders it increasingly difficult for education systems and individuals to stay connected for the skills they need (HIE, 2015). The continuous learning of new skills is ultimately essential for thriving societies, economies, and for individuals' selfactualization (Ferrara \& Nistico, 2015; Giacometti \& Cuadrado, 2020).Directly linked to this is the challenge of aligning the labour demands of the economy with the educational offers of regional 
providers. On the one hand, this generates vertical mismatches - i.e., when skill levels are either too high (overqualified) or too low (underqualified) relative to the available jobs (Cedefop, 2019). On the other hand, horizontal mismatches occur when workers are employed in a different field than the one in which they have specialised (OECD, 2017a). Thus, communication between the different actors and sectors of the education system is also a key challenge of this area of SGI (Giacometti \& Cuadrado, 2020). Moreover, vocational training schools often lack the technical equipment required to teach specific skills which are sought on the labour market.

A particularly relevant structural aspect in this SGI is the expenditure on public education, which differs significantly between the analysed countries. In Germany and Austria, below-average public spending is coupled with above-average private spending, ultimately leading to aboveaverage education levels. In Scotland, the average public spending on education, coupled with low employer contributions results in an above-average provision of private education. In Sweden, public spending is above average. Here, although employer's participation in education is low, vocational education enjoys a higher status, ultimately leading to above-average education levels (Busemeyer, 2014).

\section{Innovative approaches and new strategies}

In light of the afore-described socio-demographic and economic changes sweeping across rural areas in the past decades, a variety of strategic and operative approaches have emerged in order to maintain and adapt the quality of SGIs. Such approaches have been embedded in sectoral and territorial development policies alike. Strategic approaches take local specificities and endogenousas-

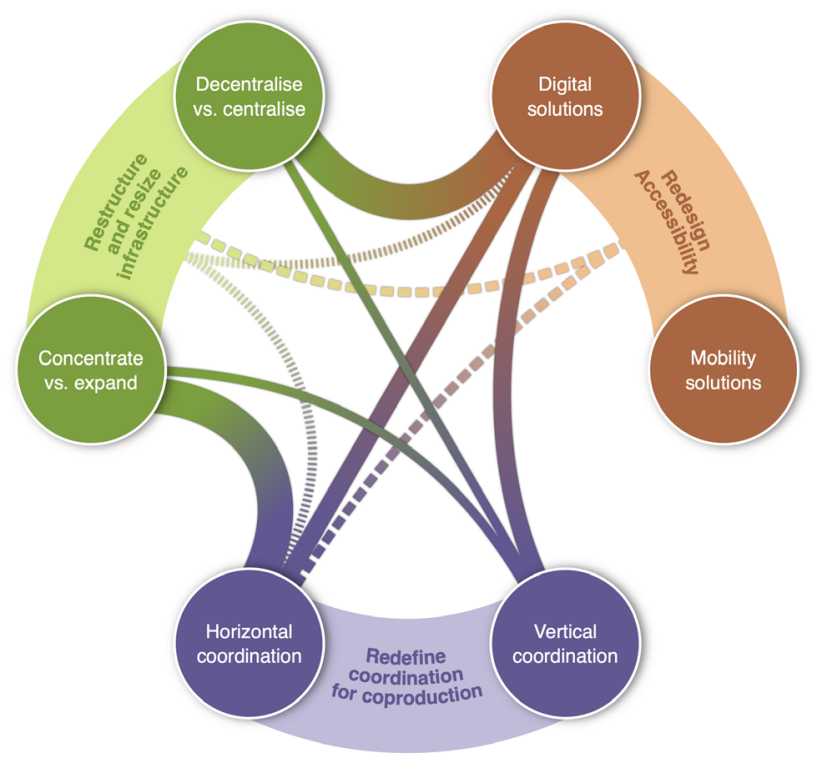

Figure 2. Main adaptation strategies in response to socio-demographic changes in rural areas The thickness of the lines represents the frequency of occurrences from 1 (thin) to 3 (thick). The dashed lines represent links between three adaptation strategies

Source: own representation based on Gatzweiler et al. (2006) and Albrecht et al. (2011). 
sets into account, enabling a constant reorganisation not only of key processes and structures, but also of the relations between key actors (public, private, and civil society) and their roles in the governance of SGIs (Santinha, 2016). In many places, these shifts have taken place under the auspice of demographic change. The mid to long-term success of these strategies and approaches usually relates to a newly enabled economic viability which is facilitated by improvements in accessibility, a balanced relationship between supply and demand, and an improved operational efficiency thanks to better coordination among involved actors.

In what follows, we discuss the main adaptation strategies of SGIs in rural areas and showcase the interrelations between them (Fig. 2). We ground this in a review of existing approaches in our three selected SGIs (Table 3).

\section{Redesigning the accessibility of SGI}

Digitalisation is a particularly prominent approach in improving the accessibility of SGIs in many rural regions (Chartier et al., 2021). Coupled with new transport and mobility solutions (car sharing, smartphone-app solutions, automatic-logarithmic routing, autonomous driving), rural regions can widen their physical and digital connectedness which in turn offers new opportunities for their population and enterprises.

Innovative approaches that address the accessibility of physical facilities, especially in medical and nursing care and education, are often found in mobility services. Examples include the use of patient and community buses or the establishment of ride-sharing benches and services. Such approaches have been tested in Sweden, Scotland, Austria, and Germany (e.g.: BMVI, 2015; Lindgren \& Berg, 2017) and usually involve digitalised booking and routing systems. This increases the efficiency of the transport service and enables the match-making between offered rides and existing demand.

In medical and nursing care, e-health applications offer promising opportunities in remote regions. Sweden can be considered a pioneer in this area, due to its long history of adopting digital health applications with public-private support (Thiel et al., 2018). Typically, the public sector owns the relevant infrastructure, while private actors develop appropriate e-health devices and applications. These innovations aim to treat and monitor patients over long distances, enabling them access to care services from their home. This includes, for example, counselling services via telephone and video consultations, or the collection and analysis of health-related patient data via sensors and apps, which in turn are directly connected to the health centre (Andersson, Hadnagy, Forsling \& Berggren, 2019). In the field of outpatient care, the use of 'information and communications technology' (e.g., video consultations or cameras for night-time monitoring) offers an increased sense of security for patients, while also relieving the professional and family caregivers (Blusi, Dalin \& Jong, 2014; Fagerström, Tuvesson, Axelsson \& Nilsson, 2017; Andersson et al., 2019). Another strategy to increase accessibility is the establishment of central community centres where patients can contact doctors and other distant health centres via tele-medical infrastructure. This service helps prevent the exclusion of patients who do not own digital devices or lack the skills to use them. While such services are common in Sweden, the testing of e-health has only been picking up during the past years in Germany and Austria (Ammenwerth et al., 2018; Berghöfer, Auschra, Deisner \& Sydow, 2020; Schweitzer, Huber, Gorfer \& Hörbst, 2020).

For fire and rescue services, the advent of digital tools has significantly improved the operational administration, creating the premises for a more efficient management of appliances and personnel. In all three studied countries, the digitalisation of central alerting functions (e.g., through emergency control centres) is a long-completed project. This enables an efficient and reliable alert- 
ing and deployment of firefighters. Digital tools also aid the coordination between different organisations responding to an incident, be it through systems, which gather information on available resources, or through maps, which facilitate access to, and display relevant assets at a scene, such as fire hydrants. Yet as interventions gain in complexity and citizens' self-help potential is rather limited, there is an expectation that organisations which coordinate interventions will expand their current role of information conveyors to organisations with an increased role in the processing and dissemination of information, with responsibilities potentially expanding into the health service (AGBF Bund \& DFV, 2020; DFV, 2020).

In post-school education, the availability of e-learning is rests on the availability of broadband internet. Massive Open Online Courses (MOOC), for instance, while not explicitly intended for rural areas, do open up new possibilities for location-independent learning (Lambert, 2020). This enables access to high-quality education in remote areas. In recent years, the democratisation of education has gone hand in hand with the new possibilities enabled throhugh e-learning (Schröder, 2016; Blayone, van Oostveen, Barber, DiGiuseppe \& Childs, 2017). Equal access to broadband is hence more relevant than ever (see Table 1). European programmes like TIBL (Technical Innovation in Blended Learning) also open up new opportunities for lifelong learning through digital means (Mazohl, Ossiannilsson \& Makl, 2018). Moreover, digital solutions can also provide individualised learning opportunities via apps. This enables the independent acquisition of language skills (Nushi \& Eqbali, 2017), resulting in a faster integration of foreigners into the labour market. This solution has the potential to address the growing problem of skilled labour scarcity in rural regions. Furthermore, online formats can also tie in with the digitalisation of the world of work by enabling the location-independent training of skilled workers, as is the case in continuous medical training (Ellaway \& Masters, 2008). Digital forms of learning decisively contribute to the lifelong learning of diverse target groups (Isaksson, Garvare, Johnson, Kuttainen \& Pareigis, 2015). Until recently, practical skills could only be trained at central locations where appropriate equipment was available. Virtual reality overcomes the distance problem by enabling the digital training of practical skills on a wide range of industrial equipment (Spilski, Lachmann, Schlittmeier \& Makhkamova, 2019). The successful establishment of digital options in the education or health sectors relies on the involvement of new experts and advisors, who can open up access to digital offers to a diverse target public (Valokivi, Carlo, Kvist \& Outila, 2021).

\section{Restructuring and resizing the infrastructure for SGI delivery}

The restructuring and resizing of SGIs can unfold new concepts of decentralization as well as centralization and should be strongly oriented towards local conditions and needs (Krajewski \& Steinführer, 2020).

In medical care, a small-scale concentrated network of multi-professional centres (employing, for example, physicians, rehabilitation specialists, and nurses) has the potential to secure the provision of rural populations. In Sweden, the first such centres were established in the 1970s and now form the most important pillar of Swedish primary care (BMVI, 2016; Ewers, Schaepe, Hämel \& Schaeffer, 2018). Germany also applies the small-scale concentration model in primary care provision. This results in a network of medical care centres, health centres, and group practices. This increases the quality of care by enabling a closely coordinated treatment delivered by different professions. The availability of various medical services in one place also helps bridge the long distances which might otherwise need to be travelled. Furthermore, the model offers family physicians fixed work contracts and the option for part-time work. In Germany, these are significant improvements over the traditional self-employed model (BMVI, 2016). The inclusion of digital solutions in such centres can also facilitate decentralised access to concentrated exper- 
tise. Swedish digital health centres are a good example in this sense. These platforms bundle the expertise of various specialists, ensuring that patients receive the best possible medical advice (Andersson et al., 2019; Meißner, 2020).

In the area of nursing care, there is a long-established trend in strengthening outpatient care and the informal care sector. In this context, a general trend towards privatization and the development of new types of care services that complement the traditional care infrastructure can be observed. One such example is the concept of social farming, delivered through farms that are certified to provide elderly care. This approach is advantageous for both sides: farmers secure another source of income, while the elderly are integrated into everyday life on the farm, receiving care in a familiar and appealing environment. This approach is mainly found in Austria, but is also currently piloted in Germany (Busch, 2020; Gramm, Giuliani \& Hoffmann, 2020).

The restructuring of fire and rescue services is in most cases a balancing act between two key parameters, namely: the impending procedural demand of reducing the operational and development costs while, on the other hand, fulfilling the legal demands of upholding and, where needed, enhancing the system's capacity to respond to incidents. A fundamental factor which shapes the spatial distribution and level of equipment of the fire stations in Germany and in some regions in Austria (Burgenland, Upper Austria) is the statutory period of time in which firefighters are required to respond to incidents. To enable the upholding of these times, German and Austrian federal states have a number of statutory instruments to their disposal. A first such adjustment enables commuting firefighters to enrol in two local fire stations - i.e., one at home and one at work. This nonetheless only marginally addresses the issue of daytime availability during working days. A second adjustment is the design of a hierarchy of fire stations, which serves as a ground for directing strategic investments. A third and final adjustment is introducing a compulsory membership to the local fire brigade by order of the mayor. Nonetheless, given the lack of motivation and potential for conflict, this is an approach that neither local authorities, nor the fire brigades desire.

Securing the service provision can also be achieved through supra-local strategic planning and coordination. In this sense, a number of publicly funded pilot projects in Germany have sought to foster inter-municipal firefighting plans. Such plans consider the existing inventory and capacity of the local fire services (particularly during the day), population projections, the reach of the fire service into the built-up areas, the financial feasibility for the local budget, and ultimately the political palatability for implementation (Albrecht, 2015; BBSR, 2009).

In Scotland, the establishment of the Scottish Fire and Rescue Service (SFRS) has brought about a number of profound changes, and serves as a good example for overlapping approaches, namely horizontal coordination, resizing and restructuring infrastructures and digital solutions (see Figure 2). Strategic interventions focused on creating a streamlined central structure with integrated administrative, IT and training systems. In the upcoming years, more profound operational changes are foreseen in the crewing model used in Retained Duty System (RDS) and volunteer fire stations, a move which is complemented by the purchasing of rapid intervention vehicles during core times (in a bid to cut the costs associated with maintaining a comprehensive, geographically dispersed fleet). Fire station closures and the removal of appliances are also an integral part of the proposed transformation, which comes bundled with a redesigned management structure that is tailored to rural areas (SFRS, 2018b; 2019). At the time of writing (May, 2021), these operational decisions are still subject to public debate and are yet to be fully implemented. Nonetheless, a key point of critique is that the service is less responsive in rural areas, with average response times increasing over the past years (SFRS, 2020b). 
Multifunctional physical facilities can be observed in the concentration of post-school educational offers in rural areas. While further education is typically offered during the day, leisure learning can take place in the evening hours. This extended use of educational facilities is particularly important in rural areas insofar as the buildings' financial feasibility is concerned. Local needs and ideas from civil society and the private sector could open up innovation centres which bring new stimuli to rural communities and bundle knowledge into one place. Shared concepts with decentralised locations also help civil society organisations and government agencies spread across remote rural regions. Linking decentralised educational institutions with e-learning offers can enrich the diversity of educational offers in rural areas (Hussain, Wang \& Rahim, 2013). On the one hand, this leads to a concentration of the development of teaching concepts with an enhanced quality. On the other hand, this approach keeps the offers within people's reach. The University of the Highlands and Islands in Scotland and Dalarna University in Sweden have been implementing decentralised and remote teaching programmes for many years (Rennie, 2003; Giglio, 2019).

\section{Redefining SGI delivery coordination for intensified coproduction}

Reconfiguring interactions and responsibilities between authorities in the administrative structure of the state and state-owned entities (vertical coordination) as well as integrating actors from the private, voluntary, and community sector for the provision of basic services and infrastructure (horizontal coordination) constitutes a third approach for adapting to socio-demographic challenges. This new configuration of interactions currently plays the central role in ensuring the provision of SGIs (ARL, 2016).

In medical and nursing care, the coordination for intensified coproduction occurs in both horizontal and vertical dynamics. Eliminating the sectoral separation between medical and nursing care in rural areas is a key move. One concept for overcoming this boundary is the use of community nurses. A trained family health nurse visits patients at home, acting as a first point of contact in monitoring the health status. Nurses are trained to make minor diagnoses and interventions, and perform essential preventive care. Community nurses help relieve the burden on rural doctors, act as a main link between patients and specialists (e.g., doctors, other nursing staff, hospitals, or healthcare providers), and help facilitate access to care by eliminating journeys that patients would otherwise have to travel. This approach involves links between horizontal coordination, redesigned accessibility, and restructuring infrastructures (see Figure 2). The solution is already established in Sweden, and is also piloted in Germany and Austria (Neumann, Gierling \& Dietzel, 2014; BMVI, 2015, 2016; Josefsson \& Peltonen, 2015; Ewers et al., 2018;).

In addition to this, new vertical models of coordination and cooperation have also emerged. One prominent approach in Sweden is the involvement of key healthcare stakeholders (e.g., municipalities, professionals, public health specialists, local enterprises, scientists) and target groups (e.g., patients) in the development of innovative approaches to medical and nursing care. To this end, the Swedish region of Norrbotten has created a platform that offers support in the further development of possible solutions to challenges within the healthcare system. From initial consultation to testing the idea in practice, the provision and design of healthcare is interactive, collaborative and offers opportunities for stakeholders to participate in their coproduction. This also enables the joint development of measures targeting rural areas (BMVI, 2015; Cedergren et al., 2021).

For fire and rescue services, three key aspects are relevant. First, the support of local companies and local administrations, which rely on volunteer and retained firefighters, is fundamental in volunteer-based firefighting systems. Yet it is often that this support is either insufficient or taken for granted. Policy recommendations in Germany make the case for campaigns which emphasise 
the benefits of employing trained volunteers (BMI, 2010), while in Scotland the need for publicly acknowledging companies which offer their support has been highlighted (HM FSI, 2020).

A second key aspect concerns the strengthening of horizontal coordination between different groups of existing and potential stakeholders in firefighting. The declining numbers of those willing to volunteer for the fire service in Germany and Scotland mandate solutions which increase the population's awareness of the volunteer and civic aspect of the firefighting system. A widespread approach in addressing this is the betterment of the links between fire brigades and other associations. A particularly relevant target group are the youth, to whom firefighting is presented as a purposeful free time activity. While in Germany and Austria, youth and children's fire-fighters are established institutions integral to volunteer fire brigades, many Scottish firefighters work with youth clubs to enthuse the young about their field. Often, such projects have a social dimension, as the clubs also offer services for at-risk children and teenagers.

Last, it must be pointed out that besides demographic challenges, the challenges faced by volunteer-based firefighting models are rooted in the shifting policy landscape. Most importantly, the immaterial value of volunteering for the firefighting service appears to have been at places lost in discussions about potentially remunerating firefighters. Nonetheless, studies argue that it is much more important that firefighters' readiness to help others is openly acknowledged by the local community. Research conducted in all the studied contexts show that this acknowledgement must not be expressed through forms of direct payment, but rather through material and immaterial incentives. Beyond distinctions, and small material compensations offered locally (Wolter, 2011; Stielike \& Vos, 2015), a paramount condition for upholding firefighters' motivation is offering modern and well-kitted work facilities (Müller, 2009).

Cooperation and coordination among relevant stakeholders can also be increasingly observed in post-school education. An example of horizontal cooperation are the regional development centres found in Sweden. There, universities and surrounding municipalities work closely together to increase the quality of education (Ljungberg \& McKelvey, 2015). The cooperation between universities and local companies is also increasingly important (Lindelöf \& Löfsten, 2004; Baraldi, Forsberg \& Severinsson, 2013; Bektas \& Tayauova, 2014). These strengthen the development of curricula relevant to the labour market and practical phases during training. Another example of successful cooperation is Akademi Norr in Northern Sweden. There, municipalities have established an educational region which facilitates the cooperation with universities, promoting the establishment of satellite locations in their area (Wallén, Garberg, Bäcklin, Hedman \& EinebrantLundén, 2020).

Rural regions in particular will depend on tailor-made educational offers to fill the gaps in the local labour market. Contributing to the fulfilling of this aim is the opening of universities to the wider population. This concept is trialled in Germany through the initiative of open universities. This aims to change the image of the university from a degree-oriented institution to an institution for lifelong learning (Buß, Erbsland, Rahn \& Pohlenz, 2018). This can be achieved through joint events or open labs where academics, entrepreneurs, and citizens work together on a topic of relevance for the region. These collaborations enable a strong link between local needs and applied research (Duh \& Kos, 2016). 
Table 3. Overview of the different approaches to solutions in the maintenance of the studied SGIs *

\begin{tabular}{|c|c|c|c|c|c|c|}
\hline & \multicolumn{2}{|l|}{ Redesign accessibility } & \multicolumn{2}{|c|}{ Restructure \& resize infrastructure } & \multicolumn{2}{|c|}{ Redefine coordination for coproduction } \\
\hline & Ditigal solutions & Transport & Concrentrate vs. expand & Decentralise vs. centralise & Vertical & Horizontal \\
\hline \multirow{3}{*}{ 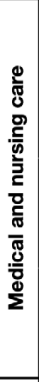 } & $\begin{array}{l}\text { E-health in medical care: enabling } \\
\text { remote treatment and patient moni- } \\
\text { toring. Consultations via telephone } \\
\text { and video, collection of health data } \\
\text { via sensors and apps. }\end{array}$ & $\begin{array}{l}\text { Patient and } \\
\text { community } \\
\text { buses, } \\
\text { ride-sharing } \\
\text { benches. }\end{array}$ & $\begin{array}{l}\text { Health care centres with } \\
\text { specialists covering different } \\
\text { professions. }\end{array}$ & $\begin{array}{l}\text { Digital health care centres } \\
\text { which pool the competences } \\
\text { of different physical centres } \\
\text { and eliminate location lock-in. }\end{array}$ & $\begin{array}{l}\text { Creating shared platforms by } \\
\text { involving key stakeholders } \\
\text { and users in the development } \\
\text { of innovations. }\end{array}$ & $\begin{array}{l}\text { Community nurses. Overcom- } \\
\text { ing sectoral separation } \\
\text { between medical and nursing } \\
\text { care. New link between } \\
\text { patients and doctors. }\end{array}$ \\
\hline & $\begin{array}{l}\text { E-health in nursing care: night-time } \\
\text { video monitoring, remote support } \\
\text { for patients and caregivers. }\end{array}$ & & \multicolumn{2}{|c|}{$\begin{array}{l}\text { Outpatient care embedded in a different context. New } \\
\text { concept of social farming (i.e. integration of the elderly into } \\
\text { everyday life on a farm). }\end{array}$} & & \\
\hline & $\begin{array}{l}\text { Central community rooms for } \\
\text { digitally contacting doctors and } \\
\text { other health centres. }\end{array}$ & & & & & \\
\hline \multirow{3}{*}{ 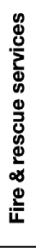 } & $\begin{array}{l}\text { Improving the administration by } \\
\text { deploying centralised IT systems. }\end{array}$ & & $\begin{array}{l}\text { Establishing Fire stations with } \\
\text { a strategic support role. }\end{array}$ & $\begin{array}{r}\text { Inter-municipal cooperation. } \\
\qquad \vartheta\end{array}$ & $\begin{array}{l}\text { Strategic coordination from } \\
\text { the top. }\end{array}$ & $\begin{array}{l}\text { Motivating local businesses to } \\
\text { support volunteer firefighting. }\end{array}$ \\
\hline & $\begin{array}{l}\text { IT solutions for enhanced tactical } \\
\text { support during an intervention. }\end{array}$ & & & $\begin{array}{l}\text { Common training and } \\
\text { resource pooling. }\end{array}$ & & $\begin{array}{l}\text { Increasing the societal } \\
\text { awareness of the role of } \\
\text { (volunteer) firefighters. }\end{array}$ \\
\hline & & & \multicolumn{2}{|c|}{ Organisational reshuffling, streamlined administration. } & & \\
\hline \multirow{3}{*}{ 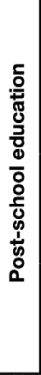 } & $\begin{array}{l}\text { Massive open online courses } \\
\text { enabling location independent } \\
\text { learning. Also used in programmes } \\
\text { like Technical Innovation in Blended } \\
\text { Learning (TIBL). }\end{array}$ & & $\begin{array}{l}\text { Multifunctional physical } \\
\text { facilities; Local idea and } \\
\text { innovation centres. }\end{array}$ & $\begin{array}{l}\text { Shared concepts with } \\
\text { decentralised locations in } \\
\text { combination with e-learning } \\
\text { offers. }\end{array}$ & $\begin{array}{l}\text { Open universities: using joint } \\
\text { events, open labs to } \\
\text { strengthen the links between } \\
\text { local needs and applied } \\
\text { research. }\end{array}$ & $\begin{array}{l}\text { Regional development } \\
\text { centres: universities and } \\
\text { surrounding municipalities } \\
\text { working closely together. }\end{array}$ \\
\hline & $\begin{array}{l}\text { Learning via app: language } \\
\text { qualification. }\end{array}$ & & & & & $\begin{array}{l}\text { Cooperation between different } \\
\text { universities for a higher quality } \\
\text { of education. }\end{array}$ \\
\hline & $\begin{array}{l}\text { Learning practical skills through } \\
\text { virtual reality. }\end{array}$ & & & & & $\begin{array}{l}\text { Cooperation between } \\
\text { universities and local } \\
\text { companies. }\end{array}$ \\
\hline
\end{tabular}

* The extent to which the study countries already use the respective approaches is reflected in the size of the flags. 
Taken together, the examples we analyse show that cooperation between different actors can secure the quality of SGIs in peripheral rural regions. Cooperation between municipalities is a worthwhile strategy, especially when budgets are limited (Gruber, Rauhut \& Humer, 2017). Cooperation between state institutions and the voluntary sector, as practiced by the fire brigades in Germany, Austria, and Scotland, must be supported and valued by state institutions (BLE, 2013). Finally, the changing distribution of roles between actors involved in the provision of SGIs also carries the risk of shifting excessive responsibility for their design and delivery to civil society and overburdening local communities and the third sector.

In summary, the innovative solutions and new strategic approaches usually appear combined in different degrees of configuration and interwovenness in practical examples and innovative projects of the named SGI areas. The links between the different adaptation strategies in Figure 2 showcase that practical examples and innovative projects generally combine two or more approaches to try and meet local or regional challenges. These adaptation strategies mirror the complexity and needs of stakeholders and adjust to the territorial specificities in question.

\section{Conclusions}

In this paper we set out to explore the challenges and adaptations of providing SGIs in European rural areas. We commenced by making a theoretical argument which depicts the notion of SGI as a fuzzy normative policy construct with multiple facets and sub-domains. We argue that the notion's intrinsic complexity can only be grasped through contextualised understandings. We make the theoretical case for doing so by delineating the key factors which have led to shifts in SGI provision in rural areas. We hence show that SGI provision is not necessarily problematic per se, but rather that the market-based demand-driven model which currently underpins its logic is at odds with the consequences of demographic changes and economic challenges in many rural areas (Fassmann et al., 2015).

We then proceed to analyse the key challenges and the solutions for overcoming these challenges for three different SGIs across four European countries. All in all, our analysis shows that different solutions are applied to similar problems across European countries (see Table 2 and Table 3). Simply put, there is no magic bullet for adapting SGIs in rural areas, as these challenges are context-bound and hence manifest themselves differently.

In spite of this variance, a number of key observations can be drawn. A first aspect relates to demographic change. This process has pushed medical and firefighting systems to their limits, both by heightening demand and by diminishing the number of qualified specialists. Digital Health Care Centres are a tried and tested solution in Sweden, being particularly successful in improving the working conditions for the medical staff and reducing the numbers of required on-site personnel. Firefighters, on the other hand, have to grapple with youth out-migration, which poses a key challenge in retaining and recruiting young firefighters. Last, the territorially-concentrated organisation of education institutions has been a traditional barrier for rural development. A decentralised organisational model coupled with e-learning (as practiced in Scotland and Sweden) come forth as viable solutions for curtailing outward-migration.

A second aspect concerns the shifts in the provision models in the face of societal changes. This has led to an increased demand for professional medical care which can no longer be provided preponderantly by relatives. A model practiced in Sweden (and piloted in Germany and Austria) enables community nurses to cover some of that demand. As far as firefighting is concerned, efforts 
are made in all analysed countries to increase the awareness of the crucial role that volunteer firefighters play in the society. In the field of education, the digitalisation of the work environment has put the spotlight on the importance of life-long learning. To respond to this, educational institutions must shed their rigid structures and become regional providers of individualised education pathways which go beyond degree courses.

A third factor involves the long distances which characterise rural territories and which pose a fundamental challenge for all analysed SGIs. Plainly put, the inflow of medical professionals is forestalled (as distances are seen to decrease the attractiveness of a place), firefighters find it difficult to attend to daytime incidents (as their commutes are long), and the equitable access to centralised services such as universities is hampered (particularly by poor public transport and broadband infrastructure). Digital solutions can offer a variety of new opportunities to overcome distance by enabling the virtual presence of professionals and remote delivery of some SGIs.

Fourth, the analysed SGIs themselves feature their own challenges. For instance, the procurement of physical assets required by fire brigades, but also by vocational schools lies beyond the financial reach of many smaller local authorities. Inter-municipal cooperation and joint strategy making are promising approaches to increase the efficiency of SGIs. Another notable example concerns the mismatch between the offered qualifications and the demands on the labour market. Addressing this requires a close cooperation between training providers and local companies.

Last, we observe that in the practical division of labour between users and providers, the boundaries between public and private have become blurred. Effective service delivery today involves more network management and multi-level planning by both groups of actors than purely sovereign regulatory tasks (Krajewski \& Steinführer, 2020). Correspondingly, government agencies are increasingly taking on the role of coordinators between the different actors in the multi-level governance system (BMEL, 2020a). Chartier et al. (2021) also use the term 'inclusive governance' in this context, which would lead to a strengthening of territorial multi-level approaches.

As market logics fall short in many rural areas, and as governmental bodies run tight budgets, we view civic engagement as a key mechanism for maintaining SGIs. The key conclusion we can draw from our research is that the establishment of a suitable full-time support system for civically organised initiatives is a salient factor which contributes to the long-term sustainability of projects seeking to improve the provision of particular SGIs. Beyond an adequate financing of private actors, it is essential to consider the ongoing involvement of experts who could aid the long-term implementation of newly developed solutions (de Haan, Meier, Haartsen \& Strijker, 2018).

While not our explicit focus in this paper, we acknowledge that research on the provision of SGIs in rural Europe in 2021 cannot ignore the impact that the COVID-19 pandemic has been exerting on SGI adaptation and transformation processes. Most notably, the importance of solidarity-based health provision beyond business efficiency has come back into focus. Moreover, the sudden en-masse adoption of digital solutions in e-health and e-learning have conferred them a wider acceptance (Valokivi et al., 2021). However, such responses are not a panacea, as they fall short of providing tailored solutions to the different needs of rural areas in Europe. We believe that advances in digitalisation must be accompanied by innovative measures and strategies which address the usability of these new tools in the face of new societal demands. Co-production in the interaction of government, local authorities, civil society organisations, and private companies will continue to be an indispensable process in addressing the challenges of maintaining SGIs. 


\section{Acknowledgements}

The research leading to these results was conducted as part of the project 'Innovative Approaches to Services of General Interest in Rural Areas - What Germany Can Learn from the Experience of other European Countries' (InDaLE). The project runs from 2020 to 2022 and is supported by funds of the Federal Ministry of Food and Agriculture (BMEL) based on a decision of the Parliament of the Federal Republic of Germany via the Federal Office for Agriculture and Food (BLE) under the Rural Development Programme. We thank the anonymous reviewers for their constructive remarks on an earlier version of this paper. We would also like to thank Annett Steinführer for her helpful comments on an earlier version of this paper.

\section{References}

AGBF Bund \& DFV (2020). Leitstelle der Zukunft: Transformation zum Dienstleister für operative Gefahrenabwehr und Informationsmanagement. Arbeitsgemeinschaft der Leiter der Berufsfeuerwehren in der Bundesrepublik Deutschland, Deutscher Feuerwehr Verband. Retrieved from https:// www.feuerwehrverband.de/app/uploads/2020/12/201111_Positionspapier_Leitstelle_der_Zukunft.pdf

Albrecht, M. (2015). Herausforderungen und Handlungsansätze im Themenfeld abwehrender Brandschutz. Erfahrungen aus anderen Bundesländern. Presentation in the conference Zukunft Brandschutz - Gestalten unter demographischen Bedingungen. Seelow (Germany).

Albrecht, M., Dehne, P., Dosch, A., Glatthaar, M., Gutsche, J.M., \& Kaether, J. (2011). Regionalstrategie Daseinsvorsorge - Denkanstöße für die Praxis. Bericht aus der Begleitforschung. Berlin-Bonn. Retrieved from http://www.regionale-daseinsvorsorge.de/fileadmin/files/pdf/Regionalstrategie_Daseinsvorsorge_Leitfaden.pdf

Ammenwerth, E., Modre-Osprian, R., Fetz, B., Gstrein, S., Krestan, S., Dörler, J., et al. (2018). HerzMobil, an Integrated and Collaborative Telemonitoring-Based Disease Management Program for Patients with Heart Failure. A Feasibility Study Paving the Way to Routine Care. JMIR Cardio, 2(1). https://doi. org/10.2196/cardio.9936

Andersson, B., Hadnagy, J., Forsling, N., \& Berggren, S. (2019). Healthcare and care through distance spanning solutions. 24 practical examples from the Nordic region. Stockholm. Retrieved from http:// www.diva-portal.org/smash/get/diva2:1386092/FULLTEXT01.pdf

ARL (2016). Daseinsvorsorge und gleichwertige Lebensverhältnisse neu denken. Perspektiven und Handlungsfelder. Hannover: Akademie für Raumordnung und Landesplanung. Retrieved from https:// shop.arl-net.de/media/direct/pdf/pospaper_108.pdf

Atterton, J., \& Skerratt, S. (2017). A Better Future for Europe's Rural Regions. Rural Policy Centre Research Report Final Report for the Council of Europe. Rural Policy Centre, Scotland's Rural College. Retrieved from https://www.sruc.ac.uk/downloads/file/3330/a_better_future_for_europe_s_rural_regions

Baraldi, E., Forsberg, P.B., \& Severinsson, K. (2013). Crafting University-Industry Interactions : A typology and empirical illustrations from Uppsala University, Sweden. In T., Kliewe, A., Meerman, P., van der Sijde \& T., Baaken (Eds.). University-Industry Interaction : Challenges and Solutions for Fostering Entrepreneurial Universities and Collaborative Innovation (pp. 157-193). Retrieved from http://urn. kb.se/resolve?urn=urn:nbn:se:uu:diva-212357

Bauby, P. (2011). From Rome to Lisbon: SGIs in Primary Law. In E., Szyszczak, J., Davies, M., Andenæs \& T., Bekkedal (Eds.). Developments in Services of General Interest (pp. 19-36). Hague: T.M.C. Asser Press.

BBSR (2009). Masterplan Daseinsvorsorge - Regionale Anpassungsstrategien. Modellvorhaben der Raumforschung (MORO). MORO-Information 4/2. Bonn: Bundesinstitut für Bau-, Stadt- und Raumforschung.

BBSR (2017). Raumordnungsbericht 2017. Daseinsvorsorge sichern. Bonn: Bundesinstitut für Bau-, Stadt-, und Raumforschung (BBSR) im Bundesamt für Bauwesen und Raumordnung (BBR). 
BBSR (2020). Raumbeobachtung - Pendler mit Arbeitsweg von $50 \mathrm{~km}$ und mehr. Bonn: Bundesinstitut für Bau-, Stadt- und Raumforschung. Retrieved from https://bbsr-geodienste.de/raumbeobachtung/

Bektas, Ç., \& Tayauova, G. (2014). A Model Suggestion for Improving the Efficiency of Higher Education: University-Industry Cooperation. Procedia - Social and Behavioral Sciences, 116, 2270-2274. https://doi.org/10.1016/j.sbspro.2014.01.558

Berghöfer, A., Auschra, C., Deisner, J., \& Sydow, J. (2020). Innovative Modelle zur Sicherung der Gesundheitsversorgung im ländlichen Raum. Zeitschrift für Allgemeinmedizin, 96(5), 198-202.

Bjørnsen, H., Foss, O., \& Johansen, S. (2015). The concept and definition of SGI. In H., Fassman, D, Rauhut, E.M., da Costa \& A., Humer (Eds.). Services of General Interest and Territorial Cohesion. European Perspectives and National Insights (pp. 49-72). Göttingen: V\&R unipress. https://doi. org/10.14220/9783737004718.49

Blayone, T.J.B., van Oostveen, R., Barber, W., DiGiuseppe, M., \& Childs, E. (2017). Democratizing digital learning: theorizing the fully online learning community model. International Journal of Educational Technology in Higher Education, 14(13). https://doi.org/10.1186/s41239-017-0051-4

BLE (2013). Daseinsvorsorge in ländlichen Räumen unter Druck. Wie reagieren auf den demografischen Wandel? Bundesanstalt für Landwirtschaft und Ernährung. Retrieved from https://www.ble-medienservice.de/7135/daseinsvorsorge-in-laendlichen-raeumen-unter-druck-wie-reagieren-auf-den-demografischen-wandel

Blusi, M., Dalin, R., \& Jong, M. (2014). The benefits of e-health support for older family caregivers in rural areas. Journal of Telemedicine and Telecare, 20(2), 9-63. https://doi.org/10.1177/1357633X13519901

BMBF (2018). Forschung und Innovation für die Menschen. Die Hightech-Strategie 2025. Berlin: Bundesministerium für Bildung und Forschung. Retrieved from https://www.hightech-strategie.de/ hightech/shareddocs/downloads/files/hts2025.pdf?__blob=publicationFile\&v=1

BMEL (2020a). Entwicklung ländlicher Räume. Dritter Bericht der Bundesregierung. Bonn: Bundesministerium für Ernährung und Landwirtschaft. Retrieved from https://www.bmel.de/SharedDocs/Downloads/DE/_laendliche-Regionen/regierungsbericht-laendliche-raeume-2020.pdf;jsessionid=DF6F66757A1593A1EBA7BFE7AA5D09B6.live851?_blob=publicationFile\&v=5

BMEL (2020b). Ländliche Regionen verstehen Fakten und Hintergründe zum Leben und Arbeiten in ländlichen Regionen. Bonn: Bundesministerium für Ernährung und Landwirtschaft. Retrieved from https://www.bmel.de/SharedDocs/Downloads/DE/Broschueren/LaendlicheRegionen-verstehen. pdf?_blob=publicationFile\&v=12

BMI (2010). Kurzexpertise: Auswirkungen des demografischen Wandels auf die Organisation der Gefahrenabwehr und Notfallrettung als Mindestleistung der öffentlichen Daseinsvorsorge. Bundesministerium des Inneren.

BMVBS (2013). Daseinsvorsorge im europäischen Vergleich - Problemwahrnehmung, Lösungsstrategien, Maßnahmen. Bundesministerium für Verkehr, Bau und Stadtentwicklung. Retrieved form https://www.bbsr.bund.de/BBSR/DE/veroeffentlichungen/ministerien/bmvbs/bmvbs-online/2013/ DL_ON042013.pdf?__blob=publicationFile\&v=2

BMVI (2015). Regionale Daseinsvorsorge in Europa - Beispiele aus ländlichen Regionen. Berlin: Bundesministerium für Verkehr und digitale Infrastruktur. Retrieved from https://www.bbsr.bund.de/ BBSR/DE/veroeffentlichungen/ministerien/moro-praxis/2015/DL_MORO_Praxis_3_15.pdf? blob=publicationFile \&v=1

BMVI (2016). Aktionsprogramm regionale Daseinsvorsorge. Abschlussbericht Projektassistenz. Berlin: Bundesministerium für Verkehr und digitale Infrastruktur. Retrieved from https://www.bbsr.bund. de/BBSR/DE/veroeffentlichungen/ministerien/bmvi/bmvi-online/2016/bmvi-online-03-16.html

Buchner, P. (2014). Ritterheer und Söldnertruppe. Eine Handlungslogik für die Schadensabwehr als Teil der Sicherheitskultur. [in:] H.J. Lange, M. Wendekamm, C. Endress, (eds.) Dimensionen der Sicherheitskultur (pp. 267-280), Wiesbaden: Springer VS.

Busch, C. (2020). Social services for seniors on farms: perspectives in Germany. In A., Steinführer, A.B., Heindl, U., Grabski-Kieron \& A., Reichert-Schick (Eds.). New rural geographies in Europe. Actors, processes, policies (pp. 65-86), Zürich: LIT.

Busemeyer, M.R. (2014). Skills and Inequality. Partisan politics and the political economy of education reforms in Western Welfare States. Cambridge: Cambridge University Press. 
Buß, I., Erbsland, M., Rahn, P., \& Pohlenz, P. (2018). Öffnung von Hochschulen. Impulse zur Weiterentwicklung von Studienangeboten. Wiesbaden: Springer.

Cedefop (2019). 2018 European skills index. Luxemburg: Publications Office of the European Union.

Cedergren, E., Huynh, D., Kull, M., Moodie, J., Sigurjonsdottier, H.R., \& Meijer, M.W. (2021). Public service delivery in the Nordic Region: an exercise in collaborative governance. Stockholm: Nordregio.

Cejudo, E., \& Navarro, F. (2020). Neoendogenous Development in European Rural Areas. Results and Lessons. Springer International Publishing.

CFS (2013). Future Challenges for Sweden. Final Report. Stockholm: Prime Minister's Office Sweden. Retrieved from https://www.government.se/4a1b92/contentassets/dd31f545664a4bc7b75d1b9bc49de292/future-challenges-for-sweden---final-report-of-the-commission-on-the-future-of-sweden.pdf

Chartier, O., Salle, E., Irvine, K., Kull, M., Miller, D., Nieto, E., et al. (2021). Long-Term Vision for Rural Areas: Contribution from SHERPA science-society-policy platforms. SHERPA Position Paper. https:// doi.org/10.5281/zenodo.4557440

Clar, C., Löschner, L., Nordbeck, R., Fischer, T., \& Thaler, T. (2021). Population dynamics and natural hazard risk management: conceptual and practical linkages for the case of Austrian policy making. Natural Hazards, 105(2), 1765-1796. https://doi.org/10.1007/s11069-020-04376-z

Clarke, J. (2007). 'It's Not Like Shopping': Citizens, Consumers and the Reform of Public Services. In M., Bevir \& F., Trentmann (Eds.). Governance, Consumers and Citizens. Agency and Resistance in Contemporary Politics (pp. 97-118). Basingstoke: Palgrave Macmillan.

Daheim, C., Wintermann, O., Glenn, J. C., Korn, J., \& Schoon, C. (2019). Work 2050: Three Scenarios. New Findings of an International Delphi Study by the Millennium Project. Bertelsmann Stiftung.

de Haan, E., Meier, S., Haartsen, T., \& Strijker, D. (2018). Defining 'Success' of Local Citizens' Initiatives in Maintaining Public Services in Rural Areas: A Professional's Perspective. Sociologia Ruralis, 58(2), 312-330. https://doi.org/10.1111/soru.12173

DFV (2018). Feuerwehr-Jahrbuch 2018. Bonn: Deutscher Feuerwehr Verband.

DFV (2020). DFV 2020 - Strategien für eine sichere Zukunft. Bonn: Deutscher Feuerwehr Verband.

Dombrowski, W.R. (2008). Die Zukunft der Freiwilligen Feuerwehren. In Deutscher Feuerwehrverband (Ed.). Feherwehr-Jahrbuch 2008 (pp. 34-36). Bonn: Köllen.

DStGB \& DFV (2020). Nationales Konzept für besonders große oder schwierige Vegetationsbrände. Deutscher Städte- und Gemeindebund \& Deutscher Feuerwehr Verband. Retrieved from https:// www.feuerwehrverband.de/app/uploads/2020/12/201005_Konzept_Vegetationsbraende_DStGB_ DFV.pdf

Duh, E.S., \& Kos, A. (2016). Fablabs as Drivers for Open Innovation and Co-creation to Foster Rural Development. International Conference on Identification, Information and Knowledge in the Internet of Things (IIKI), 214-216. https://doi.org/10.1109/IIKI.2016.70

Dunleavey, P., \& Hood, C. (1994). From old public administration to new public management. Public Money \& Management, 14(3), 9-16. https://doi.org/10.1080/09540969409387823

EC (2011). A Quality Framework for Services of General Interest in Europe. Communication from the Commission to the European Parliament, the Council, the European Economic and Social Committee and the Committee of the Regions. Brussels, 20.12.2011.

EC (2017). Seventh Report on Economic, Social and Territorial Cohesion. Luxemburg: Publications Office of the European Union. European Commission.

Ellaway, R., \& Masters, K. (2008). E-learning in medical education. Dundee. Association for Medical Education in Europe. AMEE Guide 32. Northern Ontarion-Köstendorf: School of Medicine- ITHealthEd. Retrieved from https://cfrps.unistra.fr/fileadmin/uploads/websites/cfrps/Bibliotheque/AMEE_32_-Elearning_in_medical_education_part_1_.pdf

Esping-Andersen, G. (1998). The Three Worlds of Welfare Capitalism. Princeton: Priceton University Press.

Ewers, M., Schaepe, C., Hämel, K., \& Schaeffer, D. (2018). Versorgungszentren in den ländlichen Provinzen Nordschwedens (Vårdcentraler). Stuttgart: Robert Bosch Stiftung.

Fagerström, C., Tuvesson, H., Axelsson, L., \& Nilsson, L. (2017). The role of ICT in nursing practice: an integrative literature review of the Swedish context. Scandinavian Journal of Caring Sciences, 31(3), 434-448. https://doi.org/10.1111/scs.12370 
Fassmann, H., Rauhut, D., da Costa, E.M., \& Humer, A. (Eds.) (2015). Services of general interest and territorial cohesion. European perspectives and national insights. Göttingen: V\&R Unipress.

Favry, E., \& Hiess, H. (2008). Infrastrukturen der Daseinsvorsorge in Österreichs ländlichen Gebieten. Informationen zur Raumentwicklung, 1/2, 57-69.

Fernsebner-Kokert, B., Osztovics, W., \& Kovar, A. (2018). Arena Analyse - Herausforderungen und Chancen im oberösterreichischen Gesundheitswesen. Wien: Kovar \& Partners.

Ferrara, A.R., \& Nisticò, R. (2015). Regional well-being indicators and dispersion from a multidimensional perspective: evidence from Italy. The Annals of Regional Science, 55(2-3), 373-420. https://doi. org/10.1007/s00168-015-0704-y

Fischer-Tahir, A., \& Naumann, M. (2013). Introduction: Peripheralization as the Social Production of Spatial Dependencies and Injustice. In A., Fischer-Tahir \& M., Naumann (Eds.). Peripheralization: The Making of Spatial Dependencies and Social Injustice (pp. 9-26). Wiesbaden: Springer.

Gatzweiler, H.P., Bergmann, E., Einig, K., Jakubowski, P., Kocks, M., \& Spangenberg, M. (2006). Umbau statt Zuwachs. Innovative Projekte zur Regionalentwicklung. Berlin-Bonn: Bundesministerium für Verkehr, Bau und Stadtentwicklung, Bundesamt für Bauwesen und Raumordnung.

Geier, W. (2017). Geschichte, Status quo und aktuelle Herausforderungen. In H., Karutz, W., Geier \& T., Mitschke (Eds.). Bevölkerungsschutz. Notfallvorsorge und Krisenmanagement in Theorie und Praxis (pp. 1-27). Berlin-Heidelberg: Springer.

Giacometti, A., \& Cuadrado, A. (2020). Skills supply and governance in the Bothnian Arc cross-border region. Stockholm: Nordregio. Retrieved from https://nordregio.org/publications/skills-supply-andgovernance-in-the-bothnian-arc-cross-border-region/

Giglio, A. (2019). Practicing the Oral Production Skills in E-Learning Contexts: Is It Still an Achilles' Heel? In M.L., Carrió-Pastor (Ed.). Teaching Language and Teaching Literature in Virtual Environments (pp. 21-36). Singapore: Springer Singapore.

Girard, J. (2003). Crises of Success: Elder Care in Sweden. Health Management, 5(1).

Gkartzios, M., \& Lowe, P. (2019). Revisiting Neo-Endogenous Rural Development. In M., Scott, N., Gallent \& M., Gkartzios (Eds.). The Routledge Companion to Rural Planning (pp. 159-169). New York: Routledge.

Gramm, V., Giuliani, C., \& Hoffmann, C. (2020). Soziale Landwirtschaft in Südtirol und ihre Rahmenbedingungen im europäischen Vergleich. Österreichische Zeitschrift für Soziologie, 45(1), 29-48. https:// doi.org/10.1007/s11614-020-00390-4

Gruber, E., Fassmann, H., \& Humer, A. (2015). Demographic change changing SGI demands: The example of Austria. In H., Fassman, D, Rauhut, E.M., da Costa \& A., Humer (Eds.). Services of General Interest and Territorial Cohesion. European Perspectives and National Insights (pp. 149-166). Göttingen: V\&R unipress. https://doi.org/10.14220/9783737004718

Gruber, E., Rauhut, D., \& Humer, A. (2017). Territorial cohesion under pressure? Welfare policy and planning responses in Austrian and Swedish Peripheries. Papers in Regional Science, 98(1), 115-132. https://doi.org/10.1111/pirs.12344

Hahne, U. (2009). Zukunftskonzepte für schrumpfende ländliche Räume. Von dezentralen und eigenständigen Lösungen zur Aufrechterhaltung der Lebensqualität und zur Stabilisierung der Erwerbsgesellschaft. Neues Archiv für Niedersachsen, 1, 2-25.

Halliday, J., Asthana, S., Hewson, P., \& Gibson, A. (2013). Playing with fire: Limitations of the Big Society for an emergency service. Public Policy and Administration, 28(3), 290-305. https://doi. org/10.1177/0952076712456232

HIE (2015). Digital Scotland - Highlands and Islands Research. Inverness: Highlands and Islands Enterprise. Retrieved from https://www.hie.co.uk/media/3131/measuringplustheplusdigitalpluseconomyplusinplustheplushighlandsplusandplusislandsplusfinalplusresearchplusreport.pdf

HIE (2019). Highlands and Islands key statistics 2019. Inverness: Highlands and Islands Enterprise. Retrieved from https://www.hie.co.uk/media/6341/highlandsplusandplusislandspluskeyplusstatistics.pdf

HM FSI (2020). Assessing the Effectiveness of Inspection Activity. Local Area Inspection Dumfries and Galloway. Edinburgh: HM Fire Service Inspectorate. Retrieved from https://www.gov.scot/publications/ hm-fire-service-inspectorate-assessing-effectiveness-inspection-activity/ 
Humer, A., Rauhut, D., \& Fassmann, H. (2015). The Contexts and Drivers of the Provision of Services of General Interest. In H., Fassman, D, Rauhut, E.M., da Costa \& A., Humer (Eds.). Services of General Interest and Territorial Cohesion. European Perspectives and National Insights (pp. 73-90). Göttingen: V\&R unipress. https://doi.org/10.14220/9783737004718.73

Hussain, S., Wang, Z., \& Rahim, S. (2013). E-learning Services for Rural Communities. International Journal of Computer Applications, 68(5), 15-20. https://doi.org/10.5120/11574-6888

Isaksson, R., Garvare, R., Johnson, M., Kuttainen, C., \& Pareigis, J. (2015). Sustaining Sweden's competitive position: lean lifelong learning. Measuring Business Excellence, 19(1), 92-102. https://doi. org/10.1108/MBE-11-2014-0045

Jonda, B. (2009). Wenn man gegen den Strom schwimmt und auf Kultur und Weiterbildung setzt. In C., $\mathrm{Neu}$ (Ed.). Daseinsvorsorge- Eine gesellschaftswissenschaftliche Annäherung (pp. 186-205). Wiesbaden: Verlag für Sozialwissenschaften.

Josefsson, K., \& Peltonen, S. (2015). District nurses' experience of working in home care in Sweden. Healthy Aging Research, 4(1), 37. https://doi.org/10.12715/har.2015.4.37

Krajewski, C., \& Steinführer, A. (2020). Daseinsvorsorge in ländlichen Räumen und ihre Ausgestaltung zwischen Staat, Markt und Ehrenamt. In C., Krajewski \& C.C., Wiegandt (Ed.). Land in Sicht- Ländliche Räume in Deutschland zwischen Prosperität und Peripherisierung (pp. 242-260). Bonn: Bundeszentrale für politische Bildung.

Kreiser, B. (2014). Neuniederlassung von Hausärzten im ländlichen Mecklenburg-Vorpommern. Eine qualitative Studie. Zeitschrift für Allgemeinmedizin, 90(4), 158-164. https://doi.org/10.3238/ zfa.2014.0158-0164

Kulicke, F. (2021). Auswirkungen der Digitalisierung auf die Daseinsvorsorge im Gesundheitsbereich. In A., Spellerberg (Ed.). Digitalisierung in ländlichen und verdichteten Räumen (pp. 125-134). Hannover: Akademie für Raumordnung und Landesplanung.

Lambert, S.R. (2020). Do MOOCs contribute to student equity and social inclusion? A systematic review. Computers \& Education, 145, 103693. https://doi.org/10.1016/j.compedu.2019.103693

Lang, T., \& Haunstein, S. (2017). Wachsende Regionale Polarisierung in Europa. Leipzig: Leibniz-Institut für Länderkunde. Retrieved from http://aktuell.nationalatlas.de/polarisierung_in_europa-8_092017-0-html/

Lindelöf, P., \& Löfsten, H. (2004). Proximity as a Resource Base for Competitive Advantage: University-Industry Links for Technology Transfer. Journal of Technology Transfer, 29, 311-326. https://doi. org/10.1023/B:JOTT.0000034125.29979.ae

Lindgren, H., \& Berg, J. (2017). Public transport solutions in rural areas - the current work in Sweden. Linköping: Swedish National Road and Transport Research Institute.

Ljungberg, D., \& McKelvey, M. (2015). Collaboration between Universities in Sweden. In A., Curaj, L., Georghiou, C., Harper \& E., Egron-Polak (Eds.). Mergers and Alliances in Higher Education: International Practice and Emerging Opportunities (pp. 57-81). Cham: Springer.

Machold, I., \& Tamme, O. (2009). Land am Rand? Soziale und wirtschaftliche Infrastrukturentwicklung im ländlichen Raum in Österreich. In C., Neu (Ed.). Daseinsvorsorge. Eine gesellschaftswissenschaftliche Annäherung (pp. 154-169). Wiesbaden: VS Verlag für Sozialwissenschaften.

Maclean, D. (2002). Retained, Auxiliary and Volunteer Firefighters in Scotland. Edinburgh: Scottish Executive.

Maretzke, S., Hoymann, J., Schlömer, C., \& Stelzer, A. (2021). Raumordnungsprognose 2040. BBSR-Analysen kompakt, 3. Bonn: Bundesinstitut für Bau-, Stadt- und Raumforschung.

Martin, M., \& Demyen, S. (2019, October 24-26). The role of education and professional training in local development. Historical lessons and contemporary evidence. In C., Hintea, B., Radu \& R., Suciu (Eds.). Collaborative Governance, trust building and community development. Conference proceedings. (pp. 220-235). Cluj-Napoca: Accent.

Mazohl, P., Ossiannilsson, E., \& Makl, H. (2018). Technical Innovation in Blended Learning. Concepts for the Creation of High Quality Continuous Vocational Education Courses using Multiple Devices. Conference: Special Session on Blended Learning and Quality Enhancement. https://doi. org/10.5220/0006817405480554 
Meier, M., \& Barth, U. (2007). Sind unsere freiwilligen Feuerwehren trotz demographischen Wandels "fit für die Zukunft"? Zeitschrift für Forschung und Technik im Brandschutz, 7, 147-155.

Meißner, A. (2020). Ageing and technologies - Creating a vision of care in times of digitization. Results of a fast-track process of the Joint Programming Initiative "More Years, Better Lives". Hildesheim: Stiftung Universität Hildesheim.

Mitchell, J., \& Henderson, A. (2018). Your Service, Your Voice. Public consultation on Transformation of the Scottish Fire and Rescue Service. University of Edinburgh. Retrieved from https://www. firescotland.gov.uk/media/1344651/Your_Service_Your_Voice_Public_Consultation_Analysis_v1.0.pdf

Mose, I., \& Jacuniak-Suda, M. (2016). The Highlands and Islands of Scotland in transition. Selected findings from empirical case studies in the Western Isles. Mitteilungen der Fränkischen Geographischen Gesellschaft, 61/62, 1-10.

Müller, J. (2009). Zukunft der Feuerwehr - Feuerwehr der Zukunft im ländlichen Raum. Dissertation. Bergische Universität Wuppertal.

Nadler, R. (2017). The Elephant in the Room. Über das Verhältnis von demographischem Wandel, Daseinsvorsorge und zivilgesellschaftlichem Engagement in Deutschland. Raumforschung und Raumordnung, 75(6), 499-512. https://doi.org/10.1007/s13147-017-0507-y

NCM (2020). State of the Nordic Region 2020, Nord 2020:1. Copenhagen: Nordic Council of Ministers. Retrieved from https://www.norden.org/en/publication/state-nordic-region-2020

Neumann, K., Gierling, P., \& Dietzel, J. (2014). Gute Praxis in der ambulanten Versorgung. Anregungen für Deutschland auf Basis internationaler Beispiele. Berlin: GKV Spitzenverband.

NMIS(2019). EinsatzortZukunft-Niedersachsenstelltsich den HerausforderungenderZukunftzurSicherstellung des Brandschutzes. Niedersächsisches Ministerium für Inneres und Sport. Retrieved from https:// www.landtag-niedersachsen.de/drucksachen/drucksachen_18_05000/03501-04000/18-03971.pdf

NRS (2016). Scotland Census 2011. National Records of Scotland. Retrieved from https://www.scotlandscensus.gov.uk/census-results/download-data/census-table-data/

Nushi, M., \& Eqbali, M.H. (2017). Duolingo: A mobile application to assist second language learning. Teaching English with Technology, 17(1), 89-98.

ÖBFV (2015). GLOBAL 2000: Wird Feuerwehr zur Klimawehr? Wien: Österreichischer Bundesfeuerwehrverband. Retrieved from https://www.bundesfeuerwehrverband.at/2015/08/13/global-2000wird-feuerwehr-zur-klimawehr/

ÖBFV (2017). Statistik 2017 - Ein Kurzüberblick über das Leistungsspektrum der Österreichischen Feuerwehren. Wien: Österreichischer Bundesfeuerwehrverband. Retrieved from https://www.bundesfeuerwehrverband.at/wp-content/uploads/2018/03/Statistik-2017-3.pdf

ÖBFV (2019). Positionspapier der österreichischen Feuerwehren. Wien: Österreichischer Bundesfeuerwehrverband. Retrieved from https://www.bundesfeuerwehrverband.at/wp-content/uploads/2019/10/Positionspapier-2019-1.pdf

OECD (2010). Strategies to Improve Rural Service Delivery. OECD Rural Policy Reviews. Paris: OECD Publishing.

OECD (2016). A New Rural Development Paradigm for the 21st Century: A Toolkit for Developing Countries. Paris: OECD Publishing.

OECD (2017a). Getting Skills Right: Skills for Jobs Indicators. Paris: OECD Publishing.

OECD (2017b). Sweden: Country Health Profile 2017. Paris/European Observatory on Health Systems and Policies. Brussels: OECD Publishing.

OECD (2019). Österreich: Länderprofil Gesundheit 2019, State of Health in the EU. Paris/European Observatory on Health Systems and Policy. Brussels: OECD Publishing.

OECD (2020). Health at a Glance: Europe 2020: State of Health in the EU Cycle. Paris: OECD Publishing.

OECD (2021). Delivering Quality Education and Health Care to All. Preparing Regions for Demographic Change, OECD Rural Studies. Paris: OECD Publishing.

OÖL (2012). Stand der Feuerwehrreform. Initiativprüfung. Bericht LRH-100055/18-2012-HE. Linz: Oberösterreichischer Landesrechnungshof. Retrieved from https://www.Irh-ooe.at/Mediendateien/ Berichte2012/IP_Feuerwehrwesen_Bericht.pdf

Olk, T. (2018). Engagement und Bildung. In T., Klie \& A.W., Klie (Eds.). Engagement und Zivilgesellschaft. Expertisen und Debatten zum Zweiten Engagementbericht (pp. 107-161), Wiesbaden: Springer Fachmedien. 
ÖROK (2020). STRAT.AT 2020. Partnerschaftsvereinbarung Österreich 2014-2020. Retrieved from Austrian Conference on Spatial Planning.

Pavis, S., Platt, S., \& Hubbard, G. (2000). Young people in rural Scotland Pathways to social inclusion and exclusion. Layerthorpe: Joseph Rowntree Foundation. Retrieved from https://www.jrf.org.uk/sites/ default/files/jrf/migrated/files/1859353398.pdf

Peer, V., \& Penker, M. (2016). Higher Education Institutions and Regional Development: A Meta-analysis. International Regional Science Review, 39(2), 228-253. https://doi:10.1177/0160017614531145

Pinheiro, R., Šima, K., Young, M., \& Kohoutek, J. (2018). University Complexity and Regional Development in the Periphery. In R., Pinheiro, M., Mitchell \& K., Šima (Eds.). Higher Education and Regional Development. Tales from Northern and Central Europe (pp. 1-20). Kristiansand-Prague: University I Agder-Charles University.

Rauhut, D., \& Komornicki, T. (2015, August 25-28). The challenge of SGI provision in rural areas. 55th Congress of the European Regional Science Association. Lisbon: European Regional Science Association.

Rauhut, D., Smith C., Humer, A., Ludlow, D., \& Borges, L. (2013). SeGI - Indicators and perspectives for services of general interest in territorial cohesion and development. ESPON.

Rennie, F. (2003). The use of flexible learning resources for geographically distributed rural students. Journal of Distance Education, 24(1), 25-39. https://doi.org/10.1080/01587910303052

Rennie, F. W., Greller, W., \& MacKay, M. (2002). Review of international best practice in service delivery to rural and remote areas. A Report commissioned by the Scottish Executive. Retrieved from http:// www.scotland.gov.uk/library5/social/ribp-00.asp

Richter, A., Waidelich, L., Kölmel, B., Bulander, R., Glaser, P., Proske, M., \& Brügmann, S. (2019). Digitalisation and Future Challenges in Rural Areas: An Open Innovation based Research. Proceedings of the 16th International Joint Conference on e-Business and Telecommunications, 147-153. https:// doi.org/10.5220/0007950001470153

Santinha, G. (2016). Policy integration: placing the spatial dimension in the health agenda. Evidence from Portugal. Space and Policy, 20(2), 158-176. https://doi.org/10.1080/13562576.2015.1132543

Schmitz-Veltin, A. (2006). Lebensbedingungen im demographischen Wandel. Raumforschung und Raumordnung, 64(5), 343-354. https://doi.org/10.1007/BF03184530

Schröder, C. (2016). Die digitale Bildungsrevolution? Bildungsverständnis im öffentlichen Diskurs über computergestützte, personalisierte Lernumgebungen. Master's Thesis. Kiel: Christian-Albrechts-Universität zu Kiel.

Schweitzer, M., Huber, L., Gorfer, T., \& Hörbst, A. (2020). Experiences with Developing and Using Vital Sign Telemonitoring to Support Mobile Nursing in Rural Regions. JMIR Nursing, 3(1), 1-15. https:// doi.org/10.2196/17113

SFRS (2018a). Fire safety and organisational statistics. Statistical highlights 2017-2018. Cambuslang: Scottish Fire and Rescue Service. Retrieved from https://www.firescotland.gov.uk/media/1316692/ sfrs_fso_highlights_2017_18.pdf

SFRS (2018b). Scottish Fire and Rescue Service Transformation. Cambuslang: Scottish Fire and Rescue Service. Retrieved from https://www.gov.scot/binaries/content/documents/govscot/publications/foieir-release/2018/01/foi-17-02546/documents/foi-18-02546-sfrs-presentation-transformation-pdf/ foi-18-02546-sfrs-presentation-transformation-pdf/govscot\%3Adocument/foi-18-02546\%2B-\%2BSFRS\%2Bpresentation\%2Bon\%2Btransformation.pdf

SFRS (2019). Strategic Plan 2019-22. Cambuslang: Scottish Fire and Rescue Service. Retrieved from https://www.firescotland.gov.uk/media/1476819/SFRS_Strategic_Plan_2019_22_V1.0.pdf

SFRS (2020a). Climate Change Response Plan 2045. Cambuslang: Scottish Fire and Rescue Service. Retrieved from https://www.firescotland.gov.uk/media/2190438/climatechangeresponseplan2045.pdf

SFRS (2020b). Quarterly performance report for Q1 2020-21. Cambuslang: Scottish Fire and Rescue Service. Retrieved from https://www.firescotland.gov.uk/media/2240899/20200917_CSDC19_20_ SDC_Performance_Report_2020_21_Q1_Combined.pdf

SG (2016). Fire and Rescue Framework for Scotland 2016. Edinburgh: The Scottish Government. Retrieved from https://consult.gov.scot/fire-and-rescue/fire-and-rescue-framework/supporting_documents/417276_Fire\%20Framework_V2.pdf 
Spilski, J., Lachmann, T., Schlittmeier, S., \& Makhkamova, A. (2019). Potential of VR in the vocational education and training of craftsmen. 19th International Conference on Construction Applications of Virtual Reality, Bangkok.

Statistik Austria (2015). Register-based Census 2011. Wien. Retrieved from https://www.statistik.at/ web_en/statistics/PeopleSociety/population/population_censuses_register_based_census_register_based_labour_market_statistics/index.html

Stetter, E. (2018). The EU Welfare State: Past, Present, and Future. In J.A., Ocampo \& J.E., Stiglitz, (Eds.). The Welfare State Revisited (pp. 191-212). New York: Columbia University Press.

Stielike, J., \& Vos, B. (2015). Demografischer Wandel und Freiwillige Feuerwehr: Ist mehr Geld die Lösung? BRANDSchutz/Deutsche Feuerwehr-Zeitung, 69(8), 22-25.

Syssner, J. (2020). Introduction. In J., Syssner (Ed.). Pathways to Demographic Adaptation (pp. 1-9). Cham: Springer.

Thiel, R., Deimel, L., Schmidtmann, D., Piesche, K., Hüsing, T., \& Rennoch, J. (2018). Digitalisierungsstrategien im internationalen Vergleich. Gütersloh: Bertelsmann Stiftung.

Valokivi, H., Carlo, S., Kvist, E., \& Outila, M. (2021). Digital ageing in Europe: A comparative analysis of Italian, Finnish and Swedish national policies on eHealth. Ageing and Society, 1-22. https://doi. org/10.1017/S0144686X21000945

Wallén, K., Garberg, L., Bäcklin, J., Hedman, L., \& Einebrant-Lundén, Å. (2020). Högre Utbildning i alla Kommuner? Hur kan man skapa goda förutsättningar - plats, infrastruktur och sammanhang för högre utbildning för livslångt lärande ur ett kommunalt perspektiv? University West, Department of Social and Behavioural Studies. Retrieved from https://www.diva-portal.org/smash/get/ diva2:1428735/FULLTEXT01.pdf

Wollmann, H. (2008). Reformen in Kommunalpolitik und -verwaltung. England, Schweden, Frankreich und Deutschland im Vergleich. Wiesbaden: VS Verlag für Sozialwissenschaften.

Wolter, F. (2011). Die Freiwilligen Feuerwehren in Österreich und Deutschland. Eine volkswirtschaftlich-soziologische Bestandsaufnahme. Wiesbaden: VS Verlag für Sozialwissenschaften. 